\title{
Biosynthesis of the Prosthetic Group of Citrate Lyase ${ }^{\dagger}$
}

\author{
Karin Schneider, Peter Dimroth, and Michael Bott*, \\ Institut für Mikrobiologie, Eidgenössische Technische Hochschule Zürich, Schmelzbergstrasse 7, CH-8092 Zürich, Switzerland
}

Received February 21, 2000; Revised Manuscript Received May 4, 2000

\begin{abstract}
Citrate lyase (EC 4.1.3.6) catalyzes the cleavage of citrate to acetate and oxaloacetate and is composed of three subunits $(\alpha, \beta$, and $\gamma)$. The $\gamma$-subunit serves as an acyl carrier protein (ACP) and contains the prosthetic group $2^{\prime}-\left(5^{\prime \prime}\right.$-phosphoribosyl)-3'-dephospho-CoA, which is attached via a phosphodiester linkage to serine-14 in the enzyme from Klebsiella pneumoniae. In this work, we demonstrate by genetic and biochemical studies with citrate lyase of Escherichia coli and K. pneumoniae that the conversion of apo-ACP into holo-ACP is dependent on the two proteins, $\mathrm{CitX}(20 \mathrm{kDa})$ and CitG $(33 \mathrm{kDa})$. In the absence of CitX, only apo-ACP was synthesized in vivo, whereas in the absence of $\mathrm{CitG}$, an adenylylated ACP was produced, with the AMP residue attached to serine-14. The adenylyltransferase activity of CitX could be verified in vitro with purified CitX and apo-ACP plus ATP as substrates. Besides ATP, CTP, GTP, and UTP also served as nucleotidyl donors in vitro, showing that CitX functions as a nucleotidyltransferase. The conversion of apo-ACP into holo-ACP was achieved in vitro by incubation of apo-ACP with CitX, CitG, ATP, and dephospho-CoA. ATP could not be substituted with GTP, CTP, UTP, ADP, or AMP. In the absence of CitG or dephospho-CoA, AMP-ACP was formed. Remarkably, it was not possible to further convert AMP-ACP to holo-ACP by subsequent incubation with CitG and dephospho-CoA. This demonstrates that AMP-ACP is not an intermediate during the conversion of apo- into holo-ACP, but results from a side activity of CitX that becomes effective in the absence of its natural substrate. Our results indicate that holo-ACP formation proceeds as follows. First, a prosthetic group precursor [presumably $2^{\prime}$-(5"-triphosphoribosyl)-3'-dephospho-CoA] is formed from ATP and dephospho-CoA in a reaction catalyzed by CitG. Second, holo-ACP is formed from apo-ACP and the prosthetic group precursor in a reaction catalyzed by CitX.
\end{abstract}

Citrate lyase (EC 4.1.3.6) catalyzes the $\mathrm{Mg}^{2+}$-dependent cleavage of citrate to acetate and oxaloacetate (Figure 1A). This reaction represents the initial step of all known bacterial citrate fermentation pathways $(1-4)$. Citrate lyase has been isolated from numerous bacterial species, while the biochemical characterization was performed mainly with the enzyme from Klebsiella pneumoniae (formerly Klebsiella aerogenes). It is a complex of $550 \mathrm{kDa}$, formed by six copies of each of the three different subunits $[\alpha(55 \mathrm{kDa}), \beta$ (32 $\mathrm{kDa})$, and $\gamma(11 \mathrm{kDa})](5,6)$. The catalytic activity resides on the $\alpha$ - and $\beta$-subunits, whereas the $\gamma$-subunit serves as an acyl carrier protein $(\mathrm{ACP})^{1}(7)$ containing $2^{\prime}$ - $\left(5^{\prime \prime}\right.$-phosphoribosyl)-3'-dephospho-CoA as a prosthetic group (Figure $1 \mathrm{~B})$. This group is attached by its ribose $5^{\prime}$-phosphate moiety via a phosphodiester linkage to serine-14 of the ACP $(8-$ 12). As a prerequisite for catalytic activity, the thiol group

$\doteqdot$ This work was financially supported by Boehringer Mannheim GmbH (now Roche Diagnostics GmbH), Penzberg, Germany.

* To whom correspondence should be addressed: Institut für Biotechnologie 1, Forschungszentrum Jülich, D-52425 Jülich, Germany. E-mail: m.bott@fz-juelich.de. Phone: +49 2461 615515. Fax: +49 2461612710.

Present address: Institut für Biotechnologie 1, Forschungszentrum Jülich, D-52425 Jülich, Germany.

${ }^{1}$ Abbreviations: ACP, acyl carrier protein; $\mathrm{Ap}^{\mathrm{R}}$, ampicillin resistance; ATase, adenylyltransferase; $\mathrm{Cm}^{\mathrm{R}}$, chloramphenicol resistance; DTT, dithiothreitol; IPTG, isopropyl $\beta$-D-thiogalactoside; $\mathrm{Km}^{\mathrm{R}}$, kanamycin resistance; $\mathrm{OD}_{600}$, optical density at $600 \mathrm{~nm} ; \mathrm{Tc}^{\mathrm{R}}$, tetracycline resistance; $\mathrm{X}-\mathrm{ACP}$, covalently modified ACP, identified as AMP-ACP in the course of this work.

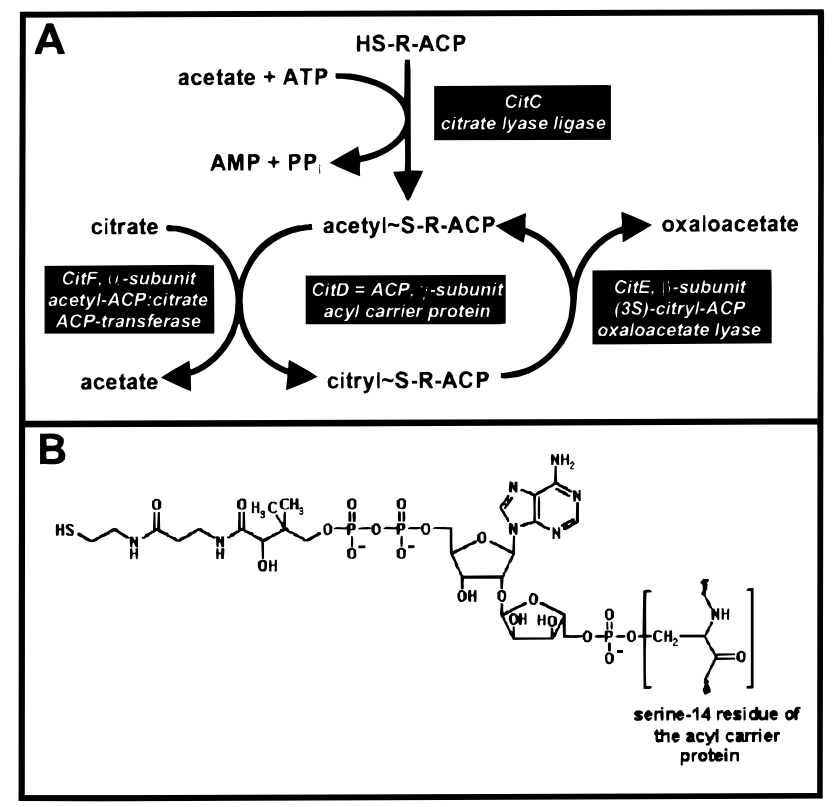

FIGURE 1: (A) Function of the different subunits in the reaction catalyzed by citrate lyase and activation of the enzyme by citrate lyase ligase. HS-R represents the prosthetic group. (B) Structure of the $2^{\prime}-\left(5^{\prime \prime}\right.$-phosphoribosyl)-3'-dephospho-CoA prosthetic group of citrate lyase.

of the enzyme-bound CoA derivative needs to be acetylated, resulting in the formation of an acetyl thioester $(7,13)$. This 
reaction is catalyzed by citrate lyase ligase (EC 6.2.1.22) in the presence of acetate and ATP (14). In the continuous turnover of the acetyl thioester during catalysis (13), the $\alpha$-subunit (acetyl-ACP:citrate ACP-transferase, EC 2.8.3.10) catalyzes the exchange of the acetyl group with a citryl group, forming acetate and citryl-ACP as products (15). The $\beta$-subunit (citryl-ACP oxaloacetate-lyase, EC 4.1.3.34) in turn catalyzes the $\mathrm{Mg}^{2+}$-dependent regeneration of acetyl-ACP through the release of oxaloacetate from citryl-ACP (15).

ACPs carrying 2'-(5"'-phosphoribosyl)-3'-dephospho-CoA as a prosthetic group have also been identified in citramalate lyase (EC 4.1.3.22) from Clostridium tetanomorphum (16), as well as in malonate decarboxylase (EC 4.1.1) from Malonomonas rubra (17), K. pneumoniae (18), and Acinetobacter calcoaceticus (19). The biosynthetic pathway of this prosthetic group has not yet been elucidated. A hypothetical mechanism was proposed suggesting that apo-ACP sequentially reacts with $\mathrm{NAD}^{+}$and dephospho-CoA to form holoACP (12).

Genetic analysis of $K$. pneumoniae citrate lyase led to the identification of the $\operatorname{cit} C D E F G$ gene cluster encoding citrate lyase ligase (CitC), the $\gamma$-subunit (CitD), the $\beta$-subunit (CitE), and the $\alpha$-subunit $(\mathrm{CitF})$ of citrate lyase, and a protein of unknown function ( $\mathrm{CitG}$ ) which was postulated to be involved in the biosynthesis of the prosthetic group (20). The $c i t C$ operon is induced under anoxic conditions in the presence of citrate and $\mathrm{Na}^{+}$ions, and its expression is strictly dependent on the $\mathrm{CitA} / \mathrm{CitB}$ two-component regulatory system $(21-23)$. Expression of the plasmid-encoded $K$. pneumoniae citCDEFG genes in Escherichia coli resulted in the formation of an inactive citrate lyase (20). However, this inactive enzyme acquired catalytic activity in the presence of acetyl coenzyme $\mathrm{A}$, which is known to substitute for the acetyl thioester of the native $2^{\prime}-\left(5^{\prime \prime}\right.$-phosphoribosyl)3 -dephospho-CoA prosthetic group (24). This and other experiments showed that the inactivity of $K$. pneumoniae citrate lyase synthesized in $E$. coli was due to the lack of the entire prosthetic group or at least of the dephospho-CoA moiety (20). Consequently, we proposed that holo-citrate lyase formation requires one or more additional enzymes, whose genes are not located in the immediate vicinity of the citCDEFG cluster on the K. pneumoniae chromosome.

With the completion of the E. coli genome sequence (25), a gene cluster that is very similar to the citCDEFG operon of $K$. pneumoniae was identified in the region between 13.9 and $14.0 \mathrm{~min}$. Most interestingly, the $E$. coli cluster contained an additional gene, named cit $X$, which was located between $c i t F$ and $c i t G$ (Figure 2) and encoded a $20 \mathrm{kDa}$ protein (26). In this work, we show that the conversion of the apo-ACP of citrate lyase into holo-ACP is dependent on $\mathrm{CitG}$ and CitX, and we present evidence for the function of the two proteins.

\section{MATERIALS AND METHODS}

Cultivation of E. coli. E. coli was routinely grown in LuriaBertani (LB) medium at $37^{\circ} \mathrm{C}(27)$. Antibiotics were added to the following final concentrations (micrograms per milliliter): ampicillin (200), chloramphenicol (40), and kanamycin (50). E. coli DH5 $\alpha$ (Bethesda Research Laboratories) was used as the host for all cloning procedures. E. coli BL21(DE3) containing the phage T7 polymerase gene under the
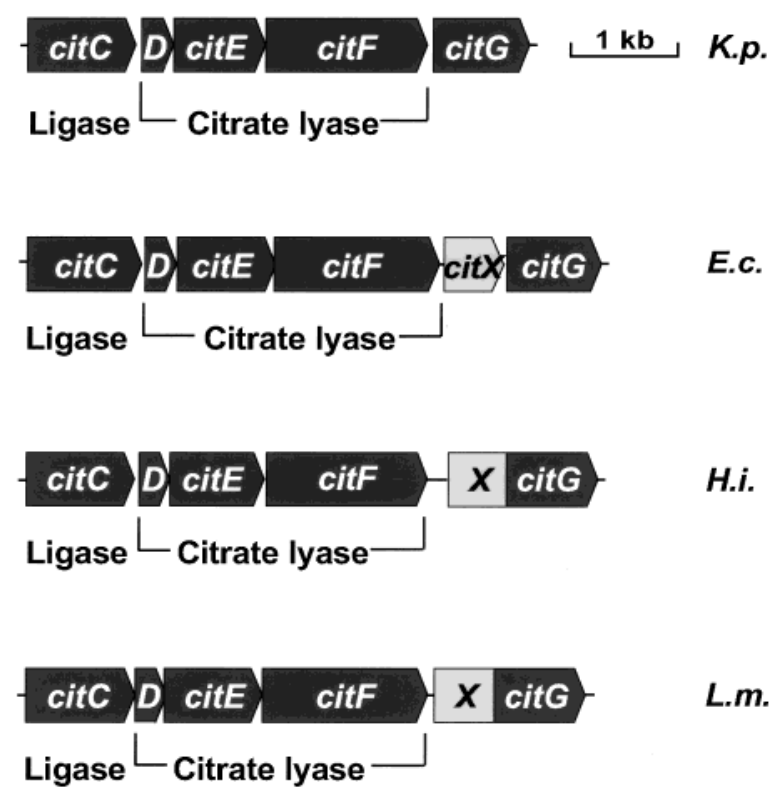

Figure 2: Citrate lyase gene clusters of K. pneumoniae (K.p.), E. coli (E.c.), H. influenzae (H.i.), and L. mesenteroides (L.m.). Gene sequences homologous to $E$. coli cit $X$ are colored light gray.

control of a lacUV5 promoter (28) served as a host for expression of target genes from pT7-7 and pET derivatives. Expression cultures were prepared as follows. After centrifugation ( $3000 \mathrm{~g}$ for $8 \mathrm{~min}$ ) of a $40 \mathrm{~mL}$ preculture grown overnight at $37^{\circ} \mathrm{C}$, the cells were resuspended in $20 \mathrm{~mL}$ of fresh LB medium. The cell suspension was subsequently used to inoculate $2 \mathrm{~L}$ of the same medium containing appropriate antibiotics, and the culture was incubated at $37^{\circ} \mathrm{C}$ and 180 $\mathrm{rpm}$. When the $\mathrm{OD}_{600}$ had reached a value between 0.5 and 0.8 , the expression of the target genes was induced by adding IPTG to a final concentration of $1 \mathrm{mM}$ and the culture was incubated for an additional $3 \mathrm{~h}$ at $37{ }^{\circ} \mathrm{C}$ and $180 \mathrm{rpm}$. Subsequently, the cells were harvested by centrifugation ( 30 min at $3000 \mathrm{~g}$ ), washed once with $20 \mathrm{~mL}$ of $50 \mathrm{mM}$ potassium phosphate buffer ( $\mathrm{pH}$ 7.0) containing $1 \mathrm{mM} \mathrm{MgCl}$, and stored at $-20{ }^{\circ} \mathrm{C}$.

Plasmids. Plasmids and oligonucleotides used in this work are listed in Tables 1 and 2, respectively. For the amplification of E. coli genes by PCR, chromosomal DNA of strain JM83 (29) or of strain CM2080 (30) was used as a template and the reaction was performed with $P f u$ DNA polymerase according to the instructions of the supplier Stratagene.

Vectors pET124b and pET224b constructed in this work are derivatives of pET24b (Novagen) carrying the p15A origin of replication derived from pACYC184 (31). This confers compatibility of the pET124b and pET224b derivatives with expression plasmids containing the ColE1 origin of replication. To obtain pET124b, the $1.19 \mathrm{~kb} B s s \mathrm{SI}-F s p \mathrm{I}$ fragment of pET24b was replaced by a $1.0 \mathrm{~kb}$ PvuII-HindIII fragment from pACYC184. Prior to ligation, the 5 '-overhangs were made blunt-ended by a fill-in reaction with Klenow polymerase. The pET224b vector was obtained by exchanging the $1.19 \mathrm{~kb} B s s \mathrm{SI}-F s p \mathrm{I}$ fragment of pET24b against a $0.9 \mathrm{~kb} P v u \mathrm{II}-S s p \mathrm{I}$ fragment from pACYC184. Again, the 5 'overhangs were made blunt-ended with Klenow polymerase. A noteworthy difference between pET224b and $\mathrm{pET} 124 \mathrm{~b}$ is the presence of a second XbaI restriction site in the latter plasmid. 


\begin{tabular}{|c|c|c|}
\hline plasmid & relevant characteristics & source/reference \\
\hline pET22b & $\mathrm{Amp}^{\mathrm{R}} ; \mathrm{lacI}^{+}$; expression vector for the production of proteins with a polyhistidine tag & Novagen \\
\hline $\mathrm{pET} 24 \mathrm{~b}$ & $\mathrm{Km}^{\mathrm{R}}$; lacl $^{+}$; expression vector for the production of proteins with a polyhistidine tag & Novagen \\
\hline pET124b & $\mathrm{Km}^{\mathrm{R}}$; lacI ${ }^{+}$; pET24b derivative with the origin of replication from pACYC184 & this work \\
\hline pET224b & $\mathrm{Km}^{\mathrm{R}} ; \mathrm{lacI}^{+} ; \mathrm{pET} 24 \mathrm{~b}$ derivative with the origin of replication from $\mathrm{pACYC} 184$ & this work \\
\hline pET224-Streptag & $\mathrm{Km}^{\mathrm{R}}$; lacI $^{+} ; \mathrm{pET} 24 \mathrm{~b}$ derivative for the production of proteins with a Strep-tag II tag & this work \\
\hline pACYC184 & $\mathrm{Cm}^{\mathrm{R}} ; \mathrm{Tc}^{\mathrm{R}} ;$ origin of $\mathrm{p} 15 \mathrm{~A}$ & 31 \\
\hline pET24-ECCL & $\mathrm{Km}^{\mathrm{R}} ;$ lacl $^{+} ;$citCDEFXG from $E$. coli in $\mathrm{pET} 24 \mathrm{~b}$ & this work \\
\hline pET124-citX & $\mathrm{Km}^{\mathrm{R}} ;$ lacI ${ }^{+} ;$cit $X$ from $E$. coli in $\mathrm{pET} 124 \mathrm{~b}$ & this work \\
\hline pET224-citXstrep & $\mathrm{Km}^{\mathrm{R}}$; lacI ${ }^{+} ;$cit $X$ from E. coli in pET224b-Streptag & this work \\
\hline pET22-citDhis & $\mathrm{Ap}^{\mathrm{R}} ;$ lacl $^{+} ;$citD from E. coli in $\mathrm{pET} 22 \mathrm{~b}$ & this work \\
\hline pET24-citGhis & $\mathrm{Km}^{\mathrm{R}}$ : lacI ${ }^{+} ;$cit $G$ from E. coli in $\mathrm{pET} 24 \mathrm{~b}$ & this work \\
\hline pET24-citGstrep & $\mathrm{Km}^{\mathrm{R}}$; lacI ${ }^{+}$; citG from $E$. coli in pET224b-Streptag & this work \\
\hline pT7-CL & $\mathrm{Ap}^{\mathrm{R}} ;$ citCDEFG from $K$. pneumoniae in $\mathrm{pT} 7-7$ & 20 \\
\hline pT7-CL $\Delta G$ & $\mathrm{Ap}^{\mathrm{R}} ;$ citCDEF from $K$. pneumoniae in pT7-7 & 20 \\
\hline
\end{tabular}

Table 2: Oligonucleotides Used in This Work ${ }^{a}$

\begin{tabular}{|c|c|}
\hline oligonucleotide & sequence \\
\hline eccl-for & 5'-CCСTCTAGAGAACAACATTCGTTGCAAATCGATAAC-3' \\
\hline ec-citT-rev & 5'-CCGCGAATTCTTAGTTCCACATGGCGAGAATCGGCCAG-3' \\
\hline ec-citX-for & 5'-AAATTTCATATGCACCTGCTTCCTGAACTCGCC-3' \\
\hline ec-citX-rev & 5'-GGGCCCCTCGAGTTAGTTGACGTTGCAGGCATCGAC-3' \\
\hline ec-citXstrep-rev & 5'-GGGCCCACTAGTGTTGACGTTGCAGGCATCGACATC-3' \\
\hline ec-citD-for & 5'-TATTATCATATGAAAATAAACCAGCCCGCCGTTGC-3' \\
\hline ec-citDhis-rev & 5'-CGCCGCCTCGAGTTGGCAATCCTCCCATGGCAGAGC-3' \\
\hline ec-citG-for & 5'-TATTATCATATGTCGATGCCTGCAACGTCAACT-3' \\
\hline ec-citGhis-rev & 5'-GGGCCCCTCGAGAATCTGTGCTAAAAACCAGGTAAG-3' \\
\hline ec-citGstrep-rev & 5'-GGGCCCACTAGTAATCTGTGCTAAAAACCAGGTAAG-3' \\
\hline strep-for & 5'-AGCTTACTAGTTGGAGCCACCCGCAGTTCGAAAAATAAC-3' \\
\hline strep-rev & 5'-TCGAGTTATTTTTCGAACTGCGGGTGGCTCCAACTAGTA-3' \\
\hline
\end{tabular}

${ }^{a}$ Restriction sites introduced by the oligonucleotides are underlined.

For the construction of an expression plasmid allowing the production of proteins with a Strep-tag II anchor (32), a linker encoding the Strep-tag II peptide WSHPQFEK was cloned into vector pET224b cut with XhoI and HindIII. This linker, which also contained an SpeI restriction site immediately upstream of the Strep-tag II coding sequence, was prepared by annealing the oligonucleotide strep-for with the complementary oligonucleotide strep-rev, which resulted in the formation of a HindIII- and an XhoI-compatible overhang. Prior to ligation, the linker was phosphorylated with polynucleotide kinase. The resulting construct was designated pET224-Streptag.

For the construction of an expression plasmid containing the $E$. coli citCDEFXG gene cluster, a $6.9 \mathrm{~kb}$ fragment was amplified by PCR using the oligonucleotides eccl-for and ec-citT-rev and the Expand High Fidelity PCR system from Roche Diagnostics. For cloning purposes, the eccl-for primer contained an $\mathrm{Xba \textrm {I }}$ restriction site. The PCR product, which also included the cit $T$ gene (26), was digested with $X b a \mathrm{I}$ and $X h o \mathrm{I}$, and the resulting $5.5 \mathrm{~kb}$ fragment was cloned into pET24b cut with the same enzymes, resulting in plasmid pET24-ECCL. The PCR-derived insert starts 55 bp upstream of the citC start codon and ends $203 \mathrm{bp}$ downstream of the $c i t G$ stop codon within the cit $T$ coding sequence.

For the construction of pET124-citX, the coding region of the E. coli citX gene was amplified by PCR using the primers ec-citX-for and ec-citX-rev. With this procedure, the start codon became part of an $\mathrm{NdeI}$ restriction site while an XhoI site was introduced immediately after the stop codon. After digestion of the PCR product with NdeI and XhoI, the $555 \mathrm{bp}$ DNA fragment was cloned into vector pET124b to yield pET124-citX. To construct plasmid pET224-citXstrep, the $c i t X$ gene was amplified using the oligonucleotides eccitX-for and ec-citXstrep-rev. Thereby, the citX stop codon was replaced with a SpeI restriction site. After digestion of the PCR product with NdeI and SpeI, the 555 bp DNA fragment was cloned into pET224-Streptag cut with the same enzymes. This led to a plasmid encoding CitX with a C-terminally attached Strep-tag II anchor.

To construct the expression plasmid pET22-citDhis, the coding region of the E. coli citD gene was amplified using primers ec-citD-for and ec-citDhis-rev that introduced an $N d e I$ restriction site at the start codon and replaced the stop codon with an XhoI restriction site, respectively. After digestion with $N d e I$ and $X h o I$, the 315 bp PCR product was cloned into pET22b cut with the same enzymes. Plasmid pET22-citDhis encodes an ACP with a C-terminally attached His tag.

For the construction of pET24-citGhis, the coding region of the E. coli cit $G$ gene was amplified by PCR using the primers ec-citG-for and ec-citGhis-rev. In this way, the start codon became part of an NdeI restriction site and the stop codon was replaced with an XhoI restriction site. After digestion with $N d e I$ and $X h o I$, the 876 bp PCR product was cloned into vector $\mathrm{pET} 24 \mathrm{~b}$ restricted with the same enzymes. The resulting plasmid pET24-citGhis encodes a CitG protein with a C-terminally attached His tag. To construct plasmid pET224-citGstrep, the cit $G$ gene was amplified using primers ec-citG-for and ec-citGstrep-rev. In this way, the start codon became part of an NdeI restriction site and the stop codon was replaced with an SpeI site. After digestion with NdeI and SpeI, the $876 \mathrm{bp} \mathrm{PCR} \mathrm{product} \mathrm{was} \mathrm{cloned} \mathrm{into} \mathrm{plasmid}$ pET224-Streptag cut with the same enzymes. This led to a 
plasmid encoding CitG with a C-terminally attached Streptag II anchor.

The correctness of the PCR-derived parts of all the plasmids described above except pET24-ECCL was verified by DNA sequencing.

Selective Labeling of Plasmid-Encoded Proteins with $\left[{ }^{35} \mathrm{~S}\right]$ Methionine. The selective $\left[{ }^{35} \mathrm{~S}\right]$ methionine labeling of proteins whose genes are under the control of a $\mathrm{T} 7$ promoter was performed essentially as described previously (33).

Preparation of Cell Extracts and Protein Determination. For the preparation of cell extracts, $1 \mathrm{~g}$ of cells (wet weight) obtained from the expression cultures was resuspended in 4 $\mathrm{mL}$ of a suitable buffer precooled on ice. For the determination of citrate lyase activity, $50 \mathrm{mM}$ potassium phosphate buffer ( $\mathrm{pH}$ 7.0) containing $1 \mathrm{mM} \mathrm{MgCl} 2$ was used. For the purification of His-tagged proteins, buffer TNI5 (see below) was employed and for the purification of Strep-tagII-tagged proteins buffer $\mathrm{W}$ (see below). After addition of a protease inhibitor cocktail (Complete Mini-EDTA free, Roche Diagnostics) and DNase I $(0.25 \mathrm{mg} / \mathrm{mL})$, the cells were disrupted by three passages through a French pressure cell at $108 \mathrm{MPa}$. Intact cells and cell debris were removed by centrifugation (30 min at $27000 g$ ). The cell-free supernatant was subjected to ultracentrifugation $(1 \mathrm{~h}$ at $150000 \mathrm{~g})$ to sediment the membrane fraction. The resulting supernatant ("cell extract") was immediately used for enzymatic studies or protein purification. Protein concentrations were determined with the bicinchoninic acid (BCA) protein assay (34) using ovalbumin as the standard.

Citrate Lyase Assay. Citrate lyase activity was determined at $25{ }^{\circ} \mathrm{C}$ in a coupled spectrophotometric assay with malate dehydrogenase essentially as described previously (20), except that only 30 units instead of 60 units of malate dehydrogenase (Roche Diagnostics) was used per assay. To convert inactive desacetyl citrate lyase to the active acetyl form, the cell extracts, which contained citrate lyase ligase ( $\operatorname{cit} C$ gene product), were incubated for $30 \mathrm{~min}$ at $37^{\circ} \mathrm{C}$ with $20 \mathrm{mM}$ acetate and $2.7 \mathrm{mM}$ ATP before they were tested in the citrate lyase assay.

Purification of $A C P_{H i s}$ and $X-A C P_{H i s}$. E. coli BL21(DE3) containing pET22-citDhis either alone or together with pET124-citX was cultured, and cell extracts were prepared using buffer TNI5 (the number indicates the imidazole concentration in millimolar), which contained $20 \mathrm{mM}$ Tris, $500 \mathrm{mM} \mathrm{NaCl}$, and $5 \mathrm{mM}$ imidazole. The $\mathrm{pH}$ of all TNI buffers was adjusted to 7.9 by addition of $\mathrm{HCl}$. Cell extracts were passed through a $0.2 \mu \mathrm{m}$ filter before being loaded onto columns containing His-bind resin in a bed volume of $2 \mathrm{~mL}$ (Novagen) equilibrated with buffer TNI5. The columns were washed with $15 \mathrm{~mL}$ of buffer TNI5, $15 \mathrm{~mL}$ of TNI30, and $10 \mathrm{~mL}$ of TNI60. Apo- $\mathrm{ACP}_{\mathrm{His}}$ or $\mathrm{X}-\mathrm{ACP}_{\mathrm{His}}$ was eluted with $10 \mathrm{~mL}$ of buffer TNI100 in fractions of $1 \mathrm{~mL}$. The proteincontaining fractions were pooled and stored at $4{ }^{\circ} \mathrm{C}$.

Purification of Cit $G_{H i s}$. E. coli BL21(DE3) containing pET24-citGhis was cultured, and cell extracts were prepared. All TNI buffers used in the purification of $\mathrm{CitG}_{\mathrm{His}}$ contained $8 \%(\mathrm{v} / \mathrm{v})$ glycerol for prevention of precipitation of the protein. Purification of $\mathrm{CitG}_{\mathrm{His}}$ was performed by $\mathrm{Ni}^{2+}$ chelate affinity chromatography as described for $\mathrm{ACP}_{\mathrm{His}}$, except that the column was washed with $15 \mathrm{~mL}$ each of buffer TNI5, TNI15, and TNI30 followed by $10 \mathrm{~mL}$ of buffer TNI60. Subsequently, $\mathrm{CitG}_{\mathrm{His}}$ was eluted with $10 \mathrm{~mL}$ of buffer TNI100 in fractions of $1 \mathrm{~mL}$. The protein-containing fractions were pooled and stored at $4{ }^{\circ} \mathrm{C}$.

Purification of Cit $X_{\text {Strep }}$ and Cit $G_{\text {Strep. }}$ E. coli BL21(DE3) harboring pET224-citXstrep or pET224-citGstrep was cultured, and a cell extract was prepared using buffer $\mathrm{W}$, which consisted of $100 \mathrm{mM}$ Tris- $\mathrm{HCl}$ (pH 8.0) and $1 \mathrm{mM}$ EDTA. The cell extract was passed through a $0.2 \mu \mathrm{m}$ filter and then loaded onto a column containing StrepTactin sepharose in a bed volume of $2 \mathrm{~mL}$ (IBA, Göttingen, Germany) equilibrated with $10 \mathrm{~mL}$ of buffer $\mathrm{W}(35)$. The column was washed with $10 \mathrm{~mL}$ of buffer $\mathrm{W}$, and $\mathrm{CitX}_{\text {Strep }}$ or $\mathrm{CitG}_{\text {Strep }}$ was eluted with $10 \mathrm{~mL}$ of buffer $\mathrm{E}$ (buffer $\mathrm{W}$ containing $2.5 \mathrm{mM}$ desthiobiotin) in $0.5 \mathrm{~mL}$ fractions. The protein-containing fractions were pooled and stored at $4{ }^{\circ} \mathrm{C}$.

Mass Spectrometric Analysis of the Different-Sized Forms of ACP. To determine the mass of the compound attached to $\mathrm{ACP}$ by $\mathrm{CitX}$, purified apo- $\mathrm{ACP}_{\mathrm{His}}$ and $\mathrm{X}-\mathrm{ACP}_{\mathrm{His}}$ were added to separate lanes of a $15 \%$ SDS-polyacrylamide gel (36). After electrophoresis, the gel was stained with GelCode Blue Stain Reagent (Pierce) until the proteins became visible. The bands were excised, and the gel slices were washed twice for $3 \mathrm{~min}$ in $100 \mathrm{mM}$ ammonium bicarbonate, cut into smaller pieces, and dried in a vacuum speed evaporator. The dried gel fragments were rehydrated with $20 \mu \mathrm{L}$ of $100 \mathrm{mM}$ ammonium bicarbonate containing $0.1 \mu \mathrm{g}$ of sequencing grade trypsin (Promega). Digestion in the gel was carried out overnight at room temperature. Peptides were extracted with $50 \mu \mathrm{L}$ of $100 \mathrm{mM}$ ammonium bicarbonate followed by two extraction steps with $50 \mu \mathrm{L}$ of an acetonitrile/formic acid $(50 \% / 5 \%)$ mixture in water. The combined extracts were reduced to a volume of $10 \mu \mathrm{L}$ in a vacuum speed evaporator.

The masses of the tryptic peptides were determined by MALDI-TOF mass spectrometry (P. James, Protein Chemistry Facility, ETH Zürich, Switzerland). Approximately 1 pmol in $0.5 \mu \mathrm{L}$ was added to the same volume of a saturated matrix solution ( $\alpha$-cyano-4-hydroxycinnamic acid in a $50 \%$ acetonitrile/1.25\% trifluoroacetic acid mixture) and allowed to dry at ambient temperature. Spectra (positive ion mode) were recorded with a Voyager Elite MALDI-TOF mass spectrometer (Perseptive Biosystems, Framingham, MA) in the delayed extraction and reflector mode using an accelerating voltage of $20 \mathrm{kV}$, a pulse delay time of $150 \mathrm{~ns}$, a grid voltage of $60 \%$, and a guide wire voltage of $0.05 \%$. Spectra were averaged from 32 scans. Calibration was external to the samples.

For the determination of intact proteins (apo- $\mathrm{ACP}_{\mathrm{His}}$ and holo- $\mathrm{ACP}_{\mathrm{His}}$ ), samples were analyzed in the delayed extraction linear mode using an accelerating voltage of $25 \mathrm{kV}$, a pulse delay time of $150 \mathrm{~ns}$, a grid voltage of $91 \%$, and a guide wire voltage of $0.1 \%$. Spectra were averaged from 32 scans.

Tandem Mass Spectrometry of the Serine-14-Containing Tryptic Peptide of ACP. The unfractionated peptide mixture obtained after tryptic in-gel digestion of apo- $\mathrm{ACP}_{\mathrm{His}}$ and $\mathrm{X}-\mathrm{ACP}_{\mathrm{His}}$ (as described above) was infused at a rate of 0.1 $\mu \mathrm{L} /$ min into a Finnigan LCQ (San Jose, CA) ion trap mass spectrometer. The electrospray source was modified to accommodate low flow rates by employing a gold-coated $15 \mu \mathrm{m}$ inside diameter spraying tip (New Objective, Inc., Cambridge, MA). Parent peptide ion isolation was performed with a mass window of 3.0 amu. Peptide fragmentation was achieved by resonance excitation with a relative energy of 
$35 \%$. MS/MS spectra were averaged from 10 scans in the centroid mode employing software provided by the manufacturer.

Cleavage of Compound $X(A M P)$ and of the Prosthetic Group from $A C P$. In vivo synthesized $\mathrm{X}-\mathrm{ACP}_{\mathrm{His}}$, in vitro synthesized putative holo- $\mathrm{ACP}_{\mathrm{His}}$, or purified $E$. coli citrate lyase was incubated for $30 \mathrm{~min}$ at $65^{\circ} \mathrm{C}$ in the presence of $0.1 \mathrm{M} \mathrm{NaOH}(8)$. After the $\mathrm{pH}$ of the solution had been adjusted to about 5 with $\mathrm{HCl}$, the precipitated protein was removed by centrifugation. The compounds that had been cleaved off by the alkaline treatment were present in the supernatant which was used for further analysis by reversed phase HPLC.

Reversed Phase Chromatography of Compound X (AMP) and of the Prosthetic Group. The HPLC analysis of compound $\mathrm{X}$ and of the prosthetic group obtained by alkaline treatment was performed essentially as described previously (17). A Hypersil ODS column $(250 \mathrm{~mm} \times 4 \mathrm{~mm}, 5 \mu \mathrm{m}$ particle size, Hewlett-Packard) was equilibrated with buffer $\mathrm{B}$ [0.2 M potassium phosphate ( $\mathrm{pH}$ 5.0)] at a flow rate of 1 $\mathrm{mL} / \mathrm{min}$. Elution was performed with a linear gradient (0 to $60 \%$ within $18 \mathrm{~min}$ ) of buffer $\mathrm{C}$ [0.2 M potassium phosphate ( $\mathrm{pH} 5.0$ ) containing $20 \%$ (v/v) acetonitrile] with UV detection at $254 \mathrm{~nm}$. The peak fractions were collected and stored at $-20{ }^{\circ} \mathrm{C}$ for further analyses. The fraction containing compound $\mathrm{X}$ was evaporated to dryness, redissolved in $\mathrm{H}_{2} \mathrm{O}$, and used for an enzymatic AMP assay.

AMP Assay. AMP was quantified in a coupled enzymatic assay with myokinase, pyruvate kinase, and lactate dehydrogenase (37). The assay mixture contained, in a final volume of $200 \mu \mathrm{L}, 100 \mathrm{mM}$ HEPES (pH 7.5), $5 \mathrm{mM} \mathrm{MgCl}$, $50 \mu \mathrm{M}$ NADH, $5 \mathrm{mM}$ PEP, $100 \mu \mathrm{M}$ ATP, 7 units of myokinase, 20 units of pyruvate kinase, and 55 units of lactate dehydrogenase (enzymes from Roche Diagnostics $\mathrm{GmbH}$ ). The reaction was started by adding different amounts of AMP or compound $\mathrm{X}$ obtained after alkaline treatment of $\mathrm{X}-\mathrm{ACP}_{\mathrm{His}}$ and subsequent reversed phase chromatography. The AMPdependent oxidation of NADH was assessed in a spectrophotometer at $340 \mathrm{~nm}\left(\epsilon=6.3 \mathrm{mM}^{-1} \mathrm{~cm}^{-1}\right)$.

\section{RESULTS}

Identification of the Genes Required for the Biosynthesis of the Prosthetic Group of Citrate Lyase. The E. coli citrate lyase gene cluster (citCDEFXG) differs from that of $K$. pneumoniae (citCDEFG) by the presence of an additional gene that we designated $\operatorname{cit} X$ (26). A database search revealed that genes homologous to $c i t X$ are also present in the citrate lyase gene clusters of Haemophilus influenzae (38), Leuconostoc mesenteroides (39), and Leuconostoc (Weissella) paramesenteroides (40). In these species, however, they are not separate genes, but are fused to the $\operatorname{cit} G$ homologues downstream (Figure 2). Thus, citX is present in all known citrate lyase gene clusters except the one of $K$. pneumoniae. Since the $K$. pneumoniae citCDEFG genes are not sufficient for the formation of holo-citrate lyase (20), we hypothesized that citX could be the gene missing in the $K$. pneumoniae cluster. In a first attempt to verify this assumption, we tested whether expression of the E. coli citCDEFXG genes results in the formation of an active citrate lyase. For this purpose, the genes were amplified by PCR and cloned into expression vector $\mathrm{pET} 24 \mathrm{~b}$, resulting in pET24-ECCL. This plasmid was introduced into $E$. coli BL21(DE3), and expression of the target genes was induced by IPTG. Extracts prepared from these cells possessed high citrate lyase activity ( $\sim 4.5$ units/ mg of protein), whereas extracts from control cells containing pET24b contained negligible activity $(<0.01 \mathrm{unit} / \mathrm{mg}$ of protein). This shows that the plasmid-encoded citCDEFXG genes are sufficient for the production of an active citrate lyase and that the chromosomally encoded citCDEFXG genes are not expressed during aerobic growth in rich medium, as expected.

We then tested whether the E. coli citX gene can complement the $K$. pneumoniae citCDEFG genes with respect to the formation of an active citrate lyase. Indeed, IPTG-induced coexpression of the corresponding genes in E. coli BL21(DE3) transformed with pET124-citX and pT7CL (20) resulted in citrate lyase activity of up to 8.2 units/ $\mathrm{mg}$ of protein in the cell-free extract. This provided conclusive evidence that $\operatorname{cit} X$ is indeed the missing gene in the $K$. pneumoniae gene cluster.

The $c i t G$ gene is present within all citrate lyase gene clusters known hitherto (Figure 2), indicating that it is involved in the biosynthesis of the prosthetic group. Since we now had a suitable assay system, we tested the role of citG in the formation of an active citrate lyase. E. coli BL21(DE3) was transformed with pET124-citX and pT7-CL $\Delta \mathrm{G}$, a derivative of pT7-CL lacking the citG gene (20), and target gene expression was induced by IPTG. Cell-free extracts prepared from these cells did not possess citrate lyase activity $(\leq 0.01$ unit/mg of protein), showing for the first time that $\mathrm{CitG}$ is essential for the formation of a functional citrate lyase.

From the results described above, it is evident that citCDEFG and citX represent the minimal set of genes required for the formation of a functional citrate lyase. Nevertheless, the exact function of $\mathrm{CitX}$ and $\mathrm{CitG}$ still remained to be elucidated. As discussed previously (20), the conversion of apo-ACP into holo-ACP involves at least two steps, i.e., the formation of the phosphodiester bond between the hydroxyl group of a serine residue and the prosthetic group and the formation of the $\alpha$-1,2-glycosidic linkage between the $5^{\prime}$-phosphoribosyl precursor and dephospho-CoA. It thus appeared possible that one of these reactions is catalyzed by $\mathrm{CitX}$ and the other by CitG. To obtain hints about the function of the two proteins, the size of the ACP was examined in the absence and in the presence of CitG and/or CitX. For this purpose, E. coli BL21(DE3) was transformed with pET124-citX in combination with either pT7-CL or pT7-CL $\Delta G$, or with each of the three plasmids separately. The plasmid-encoded proteins, whose genes are transcribed by the T7 RNA polymerase, were selectively labeled with $\left[{ }^{35} \mathrm{~S}\right]$ methionine in vivo. Whole-cell lysates were analyzed by SDS-PAGE followed by autoradiography (Figure 3 ). The apparent absence of the CitC protein $(38.5 \mathrm{kDa})$ in the autoradiogram is caused by the lower expression level of the $\operatorname{cit} C$ gene, as shown previously (20). Besides CitE (31.4 $\mathrm{kDa}), \mathrm{CitF}$ (54.7 kDa), CitG (32.6 kDa), and CitX (20.3 $\mathrm{kDa}$ ), three different-sized forms of the ACP (CitD, calculated mass of $10.4 \mathrm{kDa}$ ) were detected in this experiment, i.e., the apo form (apparent mass of $12.0 \mathrm{kDa}$ ), the holo form (apparent mass of $14.5 \mathrm{kDa}$ ), and an intermediate-sized form $(14.0 \mathrm{kDa})$ which was designated X-ACP. In the absence of CitX, only the apo form could be detected (Figure 3, lanes 3 and 4). The intermediate-sized form was synthesized in 


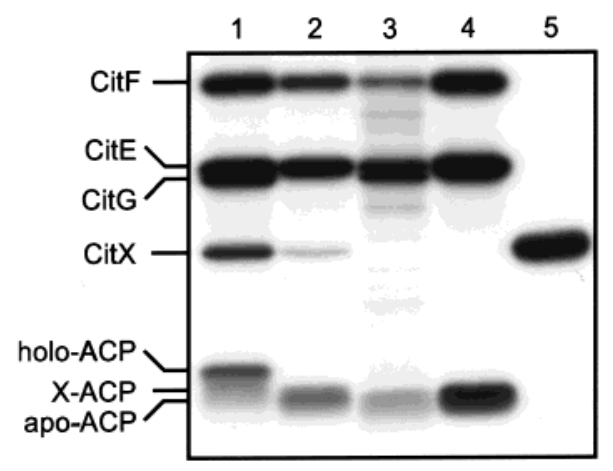

FIGURE 3: Detection of the three different-sized forms of the $K$. pneumoniae ACP. After selective $\left[{ }^{35} S\right]$ methionine labeling of proteins whose genes are transcribed by T7 RNA polymerase, the E. coli BL21(DE3) cells were harvested by centrifugation. Proteins were separated by SDS-PAGE followed by autoradiography (33). The cells harbored the following plasmids: lane 1, pT7-CL and pET124-citX; lane 2, pT7-CL $\Delta \mathrm{G}$ and pET124-citX; lane 3, pT7CL; lane 4, pT7-CL $\Delta \mathrm{G}$; and lane 5, pET124-citX.

the presence of CitX and the absence of CitG (Figure 3, lane 2). The formation of the holo form finally was dependent on the presence of both CitX and CitG (Figure 3, lane 1). These results indicate that $\mathrm{CitX}$ is responsible for the attachment of the prosthetic group to apo-ACP, whereas CitG presumably catalyzes the formation of the glycosidic linkage between dephospho-CoA and the phosphoribosyl moiety.

Identification of $X-A C P$ as $A M P-A C P$. The studies reported above gave us the opportunity to selectively synthesize $\mathrm{X}$-ACP. The identification of $\mathrm{X}$ might give clues about the precursor of the phosphoribosyl moiety, which was still unknown. To simplify our system, we presumed that the conversion of apo-ACP into holo-ACP is independent of the two other subunits of citrate lyase. Moreover, to facilitate the purification of the different ACP forms, we constructed the expression plasmid pET22-citDhis encoding a His-tagged derivative of the E. coli $\mathrm{ACP}$. The recombinant $\mathrm{ACP}_{\text {His }}$ protein (106 amino acid residues, $11.8 \mathrm{kDa}$ ) contained eight additional residues (LEHHHHHH) at its C-terminus, allowing purification by $\mathrm{Ni}^{2+}$-chelate affinity chromatography. For the synthesis of apo- $\mathrm{ACP}_{\mathrm{His}}$ and $\mathrm{X}-\mathrm{ACP}_{\mathrm{His}}, \mathrm{pET} 22$ citDhis was introduced into $E$. coli BL21(DE3) together with pET124b and pET124-citX, respectively. SDS-PAGE analysis of the ACPs purified from the two strains confirmed that the one synthesized in the presence of CitX had a larger apparent mass than the one synthesized in its absence (data not shown). We assumed that the covalent modification of ACP catalyzed by CitX would occur at serine-14, since this residue was previously shown to carry the prosthetic group of the K. pneumoniae citrate lyase (11). N-Terminal protein sequencing supported this assumption. In the case of apo$\mathrm{ACP}_{\mathrm{His}}$, the sequence XKINQPAVAGTLESGD was obtained, in agreement with the DNA-derived sequence, whereas $\mathrm{X}-\mathrm{ACP}_{\text {His }}$ yielded the same sequence except that the serine residue at position 14 could not be identified, presumably because of its modification. To obtain the mass difference between apo- $\mathrm{ACP}_{\mathrm{His}}$ and $\mathrm{X}-\mathrm{ACP}_{\mathrm{His}}$, the proteins were in-gel digested with trypsin and the resulting peptides were analyzed by MALDI-TOF mass spectrometry. As shown in Figure 4A, three dominant peaks above $1000 \mathrm{Da}$ were detected for apo-ACP, with masses of 1001.67, 1871.01, and 2099.1 Da. They correspond to tryptic peptides

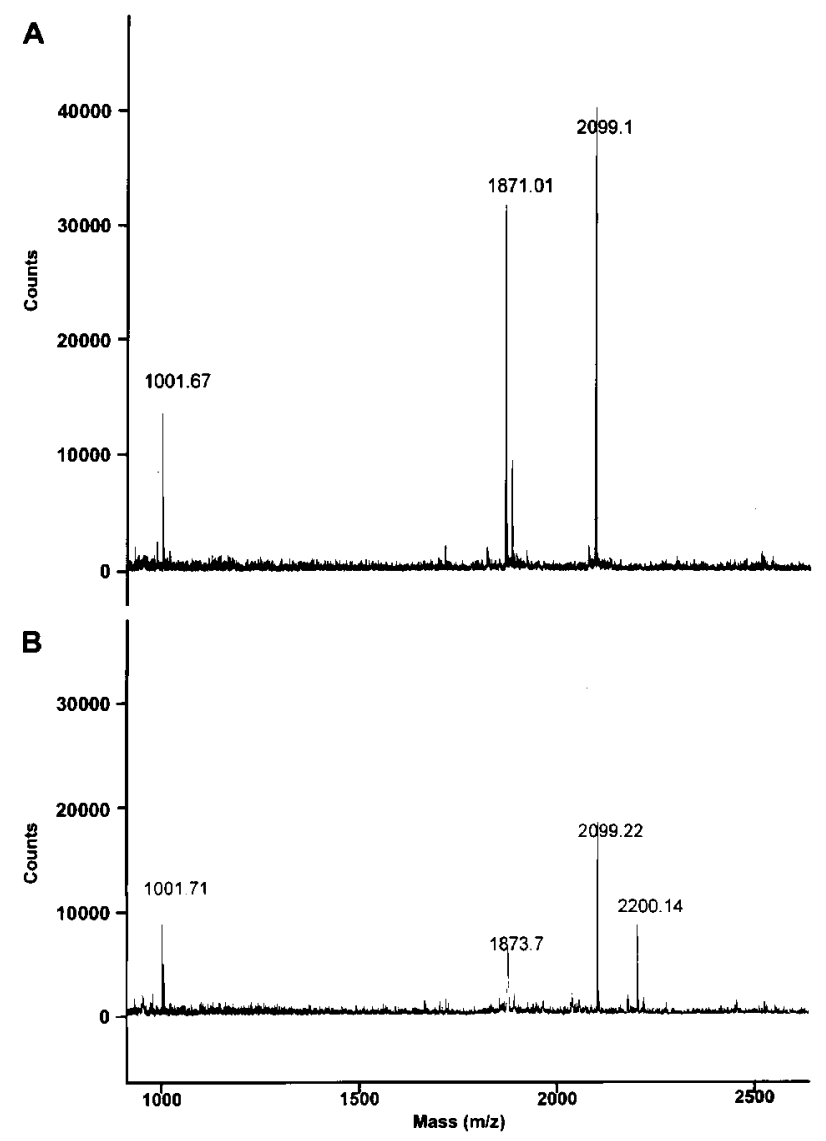

FIGURE 4: MALDI-TOF mass spectra of peptides obtained from apo- $\mathrm{ACP}_{\mathrm{His}}(\mathrm{A})$ and $\mathrm{X}-\mathrm{ACP}_{\mathrm{His}}(\mathrm{B})$ after in-gel trypsin digestion.

of apo-ACP extending from position 47 to 55 (TTILDVLAR, predicted mass of $1001.60 \mathrm{Da}$ ), from position 3 to 20 (INQPAVAGTLESGDVMIR, predicted mass of 1870.97 $\mathrm{Da}$ ), and from position 21 to 39 (IAPLDTQDIDLQINSSVEK, predicted mass of 2099.09 Da). In the mass spectrum obtained for $\mathrm{X}-\mathrm{ACP}_{\mathrm{His}}$ (Figure 4B), the 1871.01 Da peptide was replaced by a 2200.14 Da peptide, resulting in a mass difference of $329.13 \mathrm{Da}$. In addition, a mass of $1873.7 \mathrm{Da}$ was detected, which presumably represents a metastable fragment due to the broad and unresolved isotope peaks observed for this peptide compared to the others in this spectrum. To confirm that the 2200 Da peptide is a derivative of the $1871 \mathrm{Da}$ peptide, both were further analyzed by tandem mass spectrometry. Fragments that do not contain the serine residue (e.g., $b_{1}-b_{11}$ and $y_{1}-y_{6}$ ) were expected to have identical masses in both peptides, whereas those fragments including the serine residue (e.g., $b_{12}-b_{17}$ and $y_{7}-$ $\mathrm{y}_{17}$ ) should differ by $329 \mathrm{Da}$. As shown in Table 3, fragments $\mathrm{b}_{6}, \mathrm{~b}_{7}, \mathrm{~b}_{14}, \mathrm{y}_{3}, \mathrm{y}_{4}, \mathrm{y}_{11}$, and $\mathrm{y}_{12}$ corresponded with our expectations and thus confirmed that the 2200 Da peptide is a derivative of the $1871 \mathrm{Da}$ peptide. Whereas in the case of the $1871 \mathrm{Da}$ peptide 26 of the 32 major fragments corresponded to predicted masses [calculated with the software MS-Product of the University of California at San Francisco Mass Spectrometry Facility (http://donatello.ucsf.edu)], only 15 of the 33 major fragments corresponded in the case of the 2200 Da peptide. The unassigned fragments presumably represent serine-containing peptides in which the attached group (AMP, see below) was no longer intact but partially deleted by fragmentation. 
Table 3: Fragments Obtained by Tandem Mass Spectrometry of the 1871 Da Tryptic Peptide from Apo-CitD

(INQPAVAGTLESGDVMIR) and of the 2200 Da Tryptic Peptide from CitX-Modified CitD ${ }^{a}$

\begin{tabular}{|c|c|c|}
\hline measured mass & calculated mass & assignment \\
\hline \multicolumn{3}{|l|}{1871 Da peptide } \\
\hline 356.2 & 356.2 & $\mathrm{~b}_{3}$ \\
\hline 379.3 & 379.2 & QPAV-NH ${ }_{3}$ \\
\hline 394.1 & 394.2 & $\mathrm{NQPA}^{-\mathrm{NH}_{3}}$ \\
\hline 419.5 & 419.2 & $\mathrm{y}_{3}$ \\
\hline 493.3 & 493.2 & $\mathrm{NQPAV}_{-} \mathrm{NH}_{3}$ \\
\hline 518.4 & 518.3 & $\mathrm{y}_{4}$ \\
\hline 606.3 & 606.3 & $\mathrm{~b}_{6}-\mathrm{NH}_{3}$ \\
\hline 623.4 & 623.4 & $\mathrm{~b}_{6}$ \\
\hline 694.5 & 694.4 & $\mathrm{~b}_{7}$ \\
\hline 834.5 & 834.5 & $\mathrm{~b}_{9}-\mathrm{H}_{2} \mathrm{O}$ \\
\hline 906.6 & 906.4 & $\mathrm{y}_{8}$ \\
\hline 965.5 & 965.5 & $\mathrm{~b}_{10}$ \\
\hline 1019.6 & 1019.5 & $\mathrm{y}_{9}$ \\
\hline 1094.5 & 1094.6 & $\mathrm{~b}_{11}$ \\
\hline 1120.5 & 1120.6 & $\mathrm{y}_{10}$ \\
\hline 1177.6 & 1177.6 & $\mathrm{y}_{11}$ \\
\hline 1248.7 & 1248.6 & $\mathrm{y}_{12}$ \\
\hline 1329.9 & 1329.7 & $\mathrm{y}_{13}-\mathrm{H}_{2} \mathrm{O}$ \\
\hline 1347.7 & 1347.7 & $\mathrm{y}_{13}$ \\
\hline 1353.7 & 1353.7 & $\mathrm{~b}_{14}$ \\
\hline 1435.8 & 1435.7 & $\mathrm{~b}_{15}-\mathrm{NH}_{3}$ \\
\hline 1452.7 & 1452.7 & $\mathrm{~b}_{15}$ \\
\hline 1515.9 & 1515.8 & $\mathrm{y}_{15}$ \\
\hline 1583.7 & 1583.8 & $\mathrm{~b}_{16}$ \\
\hline 1696.7 & 1696.9 & $\mathrm{~b}_{17}$ \\
\hline \multicolumn{3}{|l|}{2200 Da peptide } \\
\hline 419.4 & 419.2 & $\mathrm{y}_{3}$ \\
\hline 518.5 & 518.3 & $\mathrm{y}_{4}$ \\
\hline 623.4 & 623.4 & $\mathrm{~b}_{6}$ \\
\hline 694.5 & 694.4 & $\mathrm{~b}_{7}$ \\
\hline 888.5 & 888.3 & AGTLES* \\
\hline 927.5 & 927.3 & AGTLES $* \mathrm{G}-\mathrm{H}_{2} \mathrm{O}$ \\
\hline 1257.7 & 1257.5 & TLES * GDVMI- $\mathrm{H}_{2} \mathrm{O}$ \\
\hline 1329.7 & 1329.5 & AVAGTLES*GDV \\
\hline 1442.6 & 1442.5 & AVAGTLES*GDVM- $\mathrm{H}_{2} \mathrm{O}$ \\
\hline 1506.7 & 1506.6 & $\mathrm{y}_{11} *$ \\
\hline 1577.7 & 1577.6 & $\mathrm{y}_{12} *$ \\
\hline 1682.6 & 1682.7 & $\mathrm{~b}_{14} *$ \\
\hline
\end{tabular}

${ }^{a}$ Only those masses are shown which corresponded to predicted fragments [calculated with the software MS-Product of the University of California at San Francisco Mass Spectrometry Facility (http:// donatello.ucsf.edu)]. For the $2200 \mathrm{Da}$ peptide, the masses were calculated under the assumption that the serine residue is adenylylated (see the text), resulting in a mass increase of $329 \mathrm{Da}$. The corresponding fragments are indicated with an asterisk.

$\mathrm{UV}$-vis spectra of apo- $\mathrm{ACP}_{\mathrm{His}}$ revealed an absorption maximum at $280 \mathrm{~nm}$, whereas that of $\mathrm{X}-\mathrm{ACP}_{\mathrm{His}}$ had been shifted to $264 \mathrm{~nm}$ (data not shown). This shift, which indicated that a nucleotide had been attached to ACP, and the mass difference of $329.13 \mathrm{Da}$ led us to the assumption that adenosine monophosphate (AMP) represents the compound attached to serine-14 of X-ACP. To verify our assumption, compound $\mathrm{X}$ attached to $\mathrm{ACP}_{\mathrm{His}}$ by $\mathrm{CitX}$ was cleaved off by alkaline treatment and subsequently analyzed by reversed phase HPLC (Figure 5). The elution profile revealed one major peak with a retention time of $7.4 \mathrm{~min}$. When $\mathrm{X}$ and commercially available $5^{\prime}$-AMP at concentrations of $0.1 \mathrm{mM}$ were cochromatographed, AMP coeluted with the peak at $7.4 \mathrm{~min}$, providing convincing evidence that the majority of compound $\mathrm{X}$ is identical with AMP. The 7.4 min HPLC fraction had the same UV absorption spectrum as $5^{\prime}$-AMP with a maximum at $259 \mathrm{~nm}$ (not shown). After evaporation to dryness and dissolution in $\mathrm{H}_{2} \mathrm{O}$, the compound

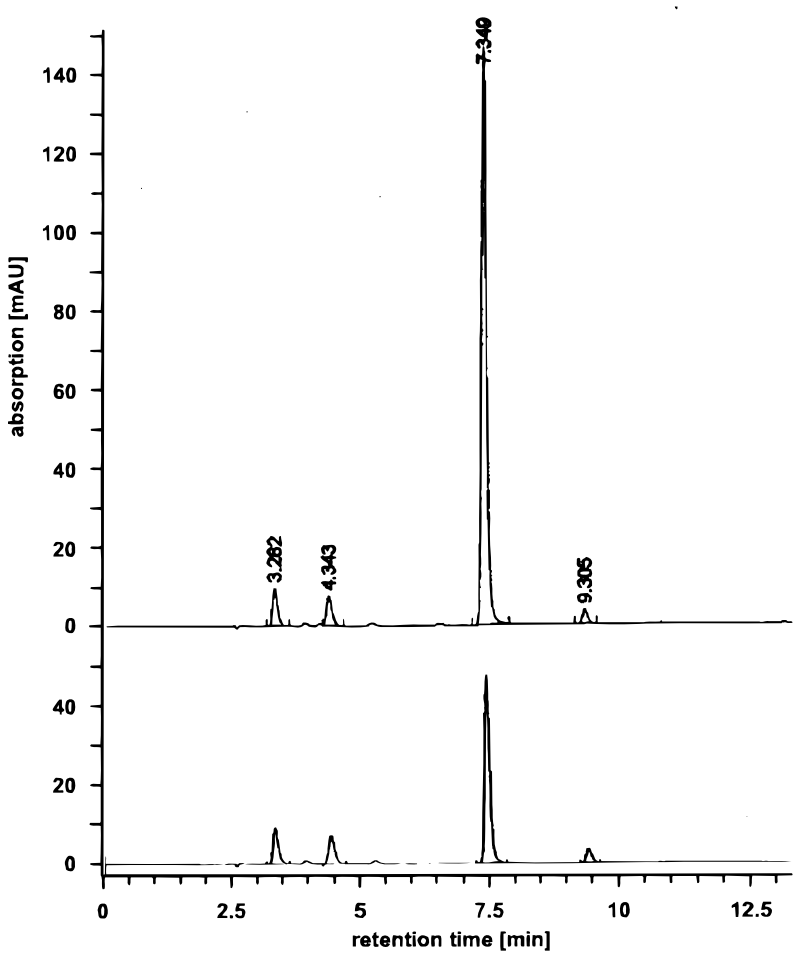

FIGURE 5: Coelution of AMP and the compound obtained after alkaline treatment of $\mathrm{X}-\mathrm{ACP}_{\text {His }}$ during reversed phase HPLC. Purified $\mathrm{X}-\mathrm{ACP}_{\mathrm{His}}$ was treated with $0.1 \mathrm{M} \mathrm{NaOH}$ for $30 \mathrm{~min}$ at 65 ${ }^{\circ} \mathrm{C}$ to cleave off compound $\mathrm{X}$. After $\mathrm{pH}$ adjustment to 5.0 with $\mathrm{HCl}$ and removal of the precipitated protein by centrifugation, the compound cleaved off was subjected to HPLC either without added AMP (bottom) or together with commercially available AMP (top). For detection, the UV absorption at $254 \mathrm{~nm}$ was measured.

was tested in a coupled enzymatic AMP assay with myokinase, pyruvate kinase, and lactate dehydrogenase (37). Myokinase is absolutely specific for adenosine phosphates and does not react with other nucleoside phosphates. Addition of different amounts of $\mathrm{X}$ to the assay mixture resulted in NADH oxidation, and the AMP concentration measured by this assay agreed roughly with the one calculated from the absorption at $260 \mathrm{~nm}$ using an extinction coefficient of 15.0 $\mathrm{mM}^{-1} \mathrm{~cm}^{-1}$. These results provide additional support for the identity of compound $\mathrm{X}$ with $5^{\prime}$-AMP.

In Vitro Conversion of Apo-ACP into AMP-ACP Using Purified CitX. The identification of X-ACP as adenylylated ACP suggested that ATP is the donor of the adenylyl group and that CitX possesses adenylyltransferase activity. To verify these assumptions, we established an in vitro system for the conversion of apo- $\mathrm{ACP}_{\text {His }}$ into $\mathrm{AMP}-\mathrm{ACP}_{\mathrm{His}}$ with purified proteins. For this purpose, the expression plasmid pET224-citXstrep was constructed, encoding a CitX derivative with the Strep-tag II peptide (32). CitX $\mathrm{X}_{\text {Strep }}$ (193 amino acid residues, $21.5 \mathrm{kDa}$ ) contained 10 additional residues (TSWSHPQFEK) at the C-terminus, which allowed purification by StrepTactin affinity chromatography (35). For the in vitro assay, apo- $\mathrm{ACP}_{\text {His }}(19 \mu \mathrm{M})$ and $\mathrm{CitX}_{\text {Strep }}(5 \mu \mathrm{M})$ were mixed in either the presence or absence of $6 \mathrm{mM}$ ATP. At different times after the start of the reaction, samples were taken and analyzed by SDS-PAGE (Figure 6). In the samples containing ATP, the conversion of apo- $\mathrm{ACP}_{\mathrm{His}}$ into a slightly larger form could be observed, which was completed after 5 min under our reaction conditions. In the samples without ATP, no conversion of the apo- $\mathrm{ACP}_{\text {His }}$ was 


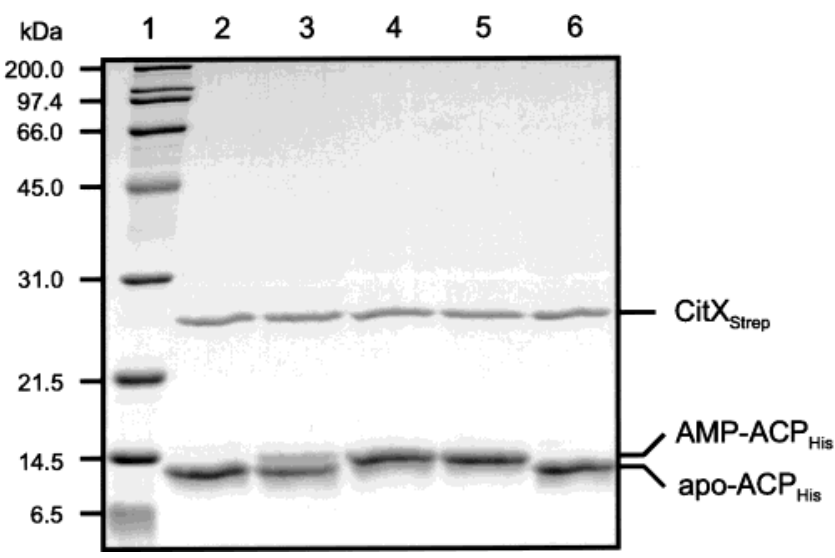

FIGURE 6: ATP-dependent in vitro conversion of apo-ACP into AMP-ACP. Purified apo-ACP $\mathrm{Ais}_{\mathrm{His}}(19 \mu \mathrm{M})$ and $\mathrm{CitX}_{\text {Strep }}(5 \mu \mathrm{M})$ were incubated at room temperature in the absence (lanes 2 and 6) and in the presence of $6 \mathrm{mM}$ ATP (lanes 3-5). Aliquots were taken 0 , 5 , and 30 min after the start of the reaction with $\mathrm{CitX}_{\text {Strep }}$, mixed with an equal volume SDS sample buffer, and subjected to SDSPAGE. The gel was subsequently stained with Coomassie brilliant blue: lane 1, protein standard; lanes 2 and 3, 0 min; lane 4, $5 \mathrm{~min}$; and lanes 5 and 6, $30 \mathrm{~min}$.

detected. To confirm the nature of the modification, the in vitro produced putative $\mathrm{AMP}-\mathrm{ACP}_{\mathrm{His}}$ was in-gel digested with trypsin and the resulting peptides were subjected to MALDI-TOF mass spectrometry. The resulting chromatogram (not shown) revealed peptide masses that were identical to those obtained with AMP-ACP $\mathrm{His}_{\mathrm{His}}$ synthesized in vivo. This result showed that $\mathrm{CitX}$ alone is sufficient to catalyze the ACP adenylyltransferase reaction.

To test the substrate specificity of CitX, ATP was replaced with GTP, CTP, or UTP. Remarkably, apo-ACP was converted to a larger-sized form with each of these nucleoside triphosphates (rates in the following order, CTP $>$ GTP and UTP). Thus, CitX could use different nucleotides and functioned as a nucleotidyltransferase. Since $\mathrm{NAD}^{+}$had been proposed as a possible precursor of the phosphoribosyl moiety of the citrate lyase prosthetic group (12), we also tested whether apo-ACP could be modified by CitX with $\mathrm{NAD}^{+}$as a substrate. No conversion of apo-ACP into a larger-sized form was observed in this experiment.

In Vitro Conversion of Apo-ACP into Holo-ACP with Purified CitX and CitG. The experiments described above indicated that the formation of AMP-ACP could be the first step in the synthesis of holo-ACP. The second one then would be the displacement of the adenine moiety by the 2-hydroxyl group of dephospho-CoA catalyzed by CitG. However, it is also possible that in vivo first a precursor of the prosthetic group is formed and then transferred to apoACP by CitX. To distinguish between these possibilities, we set up an in vitro system for the conversion of apo- $\mathrm{ACP}_{\text {His }}$ into holo- $\mathrm{ACP}_{\mathrm{His}}$ with purified components. For this purpose, the plasmid pET24-citGhis was constructed encoding a Histagged derivative of the E. coli $\mathrm{CitG}$ protein. The recombinant $\mathrm{CitG}_{\mathrm{His}}$ (300 amino acids, $32.7 \mathrm{kDa}$ ) contained eight additional amino acid residues at its C-terminus (LEHHH$\mathrm{HHH}$ ) and was purified by $\mathrm{Ni}^{2+}-$ chelate affinity chromatography.

In a first set of experiments, apo- $\mathrm{ACP}_{\mathrm{His}}(32 \mu \mathrm{M})$ was incubated at room temperature with $\mathrm{CitX}_{\text {Strep }}(\sim 8 \mu \mathrm{M})$, $\mathrm{CitG}_{\mathrm{His}}(\sim 4 \mu \mathrm{M})$, ATP $(1 \mathrm{mM})$, and dephospho-CoA (1
$\mathrm{mM})$. Aliquots were taken 0,15 , and $30 \mathrm{~min}$ after start of the reaction with ATP and subjected to SDS-PAGE. As shown in Figure 7 (lanes 2-4), the apparent size of the ACP increased from about $12.5 \mathrm{kDa}$ (apo form) to about $15.0 \mathrm{kDa}$. Conversion was almost complete after $15 \mathrm{~min}$, and an intermediate-sized form was not detectable. When dephospho-CoA was omitted from the assay, the apparent ACP size increased from 12.5 to $14.5 \mathrm{kDa}$, which corresponds to AMP$\mathrm{ACP}_{\text {His }}$ (Figure 7, lanes 5-7). The minor protein band with a size of $15 \mathrm{kDa}$ visible in lanes 5-10 represents a degradation product of $\mathrm{Cit}_{\text {Strep }}$ rather than an ACP form. When either ATP or Cit $\mathrm{X}_{\text {Strep }}$ was omitted from the assay, no conversion of apo- $\mathrm{ACP}_{\mathrm{His}}$ into a larger-sized form was observed (Figure 7, lanes 8-13). When apo- $\mathrm{ACP}_{\mathrm{His}}$ was incubated with ATP, dephospho-CoA, and $\mathrm{CitX}_{\text {Strep }}$, but without $\mathrm{CitG}_{\mathrm{His}}$, only $\mathrm{AMP}-\mathrm{ACP}_{\mathrm{His}}$ was formed (data not shown). These results indicate that the ACP with an apparent size of $15.0 \mathrm{kDa}$ represents the holo form and that its formation is dependent on dephospho-CoA, ATP, CitX, and CitG. In contrast to the previous experiments on the conversion of apo-ACP by CitX alone, ATP could not be replaced by GTP, CTP, or UTP in the formation of the putative holoACP. Moreover, ATP could not be substituted by ADP or AMP. These data indicate that ATP is the only precursor of the phosphoribosyl moiety of the prosthetic group and that both the adenine and the triphosphate moiety are essential for holo-ACP formation.

To confirm that the in vitro formed ACP with an apparent size of $15.0 \mathrm{kDa}$ in fact represents the holo form, it was in-gel digested with trypsin and the resulting peptides were analyzed by MALDI-TOF mass spectrometry. We expected that the 1871 Da peptide containing serine-14 was replaced by a 2754 Da peptide, caused by the attachment of the 883 Da prosthetic group. Although the $1871 \mathrm{Da}$ peptide was indeed absent in the mass spectrum of the tryptically digested $15.0 \mathrm{kDa} \mathrm{ACP}$, a peptide with a mass of $2754 \mathrm{Da}$ was not detectable (data not shown). We tried different protocols for in-gel trypsin digestion, as well as trypsin digestion in solution of either native or urea-denatured protein, but in no case could a peptide of the expected size be identified by MALDI-TOF mass spectrometry. Therefore, two alternative approaches were used to verify the identity of the prosthetic group of the in vitro formed $15.0 \mathrm{kDa} \mathrm{ACP}$.

(i) The masses of undigested apo- $\mathrm{ACP}_{\mathrm{His}}(12.5 \mathrm{kDa})$ and of undigested putative holo- $\mathrm{ACP}_{\text {His }}(15.0 \mathrm{kDa})$ were determined by MALDI-TOF mass spectrometry in the linear mode. To purify the different $\mathrm{ACP}_{\text {His }}$ forms from the assay mixtures by $\mathrm{Ni}^{2+}$-chelate affinity chromatography, we replaced $\mathrm{CitG}_{\mathrm{His}}$ by a CitG protein tagged with a Strep-tag II peptide. For this purpose, the expression plasmid pET224citGstrep was constructed. The recombinant $\mathrm{CitG}_{\text {Strep }}$ protein (302 amino acid residues, $32.9 \mathrm{kDa}$ ) contained 10 additional residues (TSWSHPQFEK) at its C-terminus and was isolated by StrepTactin affinity chromatography (35). The assay mixture for in vitro conversion of apo- into holo-ACP contained $50 \mu \mathrm{M}$ apo- $\mathrm{ACP}_{\mathrm{His}}, 2.5 \mu \mathrm{M}$ CitX $\mathrm{X}_{\text {Strep }}, 4 \mu \mathrm{M}$ $\mathrm{CitG}_{\text {Strep }}, 1 \mathrm{mM}$ ATP, and $1 \mathrm{mM}$ dephospho-CoA. In an otherwise identical control reaction, ATP was omitted to prevent the conversion of apo- $\mathrm{ACP}_{\mathrm{His}}$. After incubation for 90 min at room temperature, the different forms of $\mathrm{ACP}_{\text {His }}$ were purified from the two reaction mixtures using $\mathrm{Ni}^{2+}-$ 


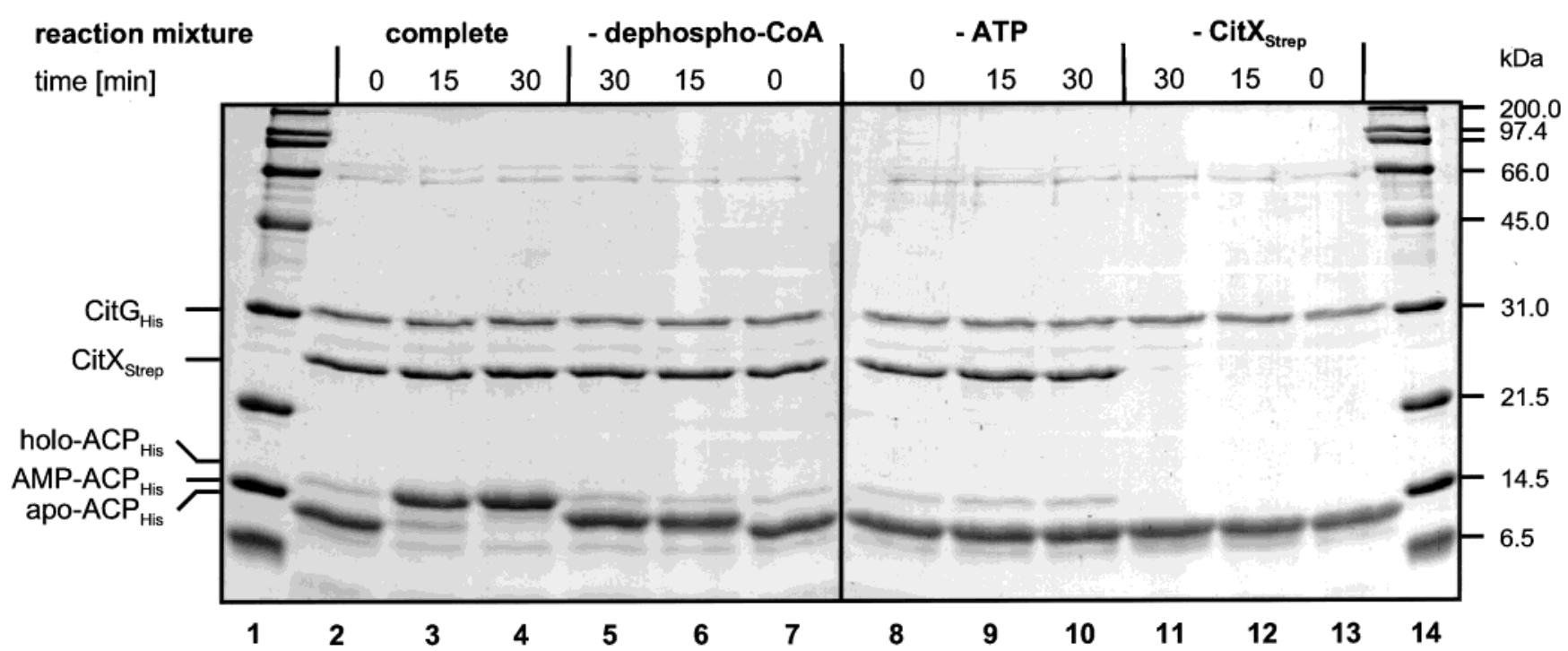

FIGURE 7: In vitro conversion of apo-ACP into holo-ACP. Apo-ACP $\mathrm{His}_{\mathrm{H}}(32 \mu \mathrm{M})$ was incubated at room temperature with $\mathrm{CitG}$ His $(\sim 4 \mu \mathrm{M})$, CitX $_{\text {Strep }}(\sim 8 \mu \mathrm{M})$, ATP $(1 \mathrm{mM})$, and dephospho-CoA $(1 \mathrm{mM})$. Aliquots were taken 0,15 , and 30 min after the start of the reaction with ATP and subjected to SDS-PAGE (lanes 2-4). Besides this complete assay mixture, three others were analyzed which lacked either dephospho-CoA (lanes 5-7), ATP (lanes 8-10), or CitX $\mathrm{X}_{\text {Strep }}$ (lanes 11-13). Lanes 1 and 14 contained the protein standard. The gel was stained with Coomassie brilliant blue.

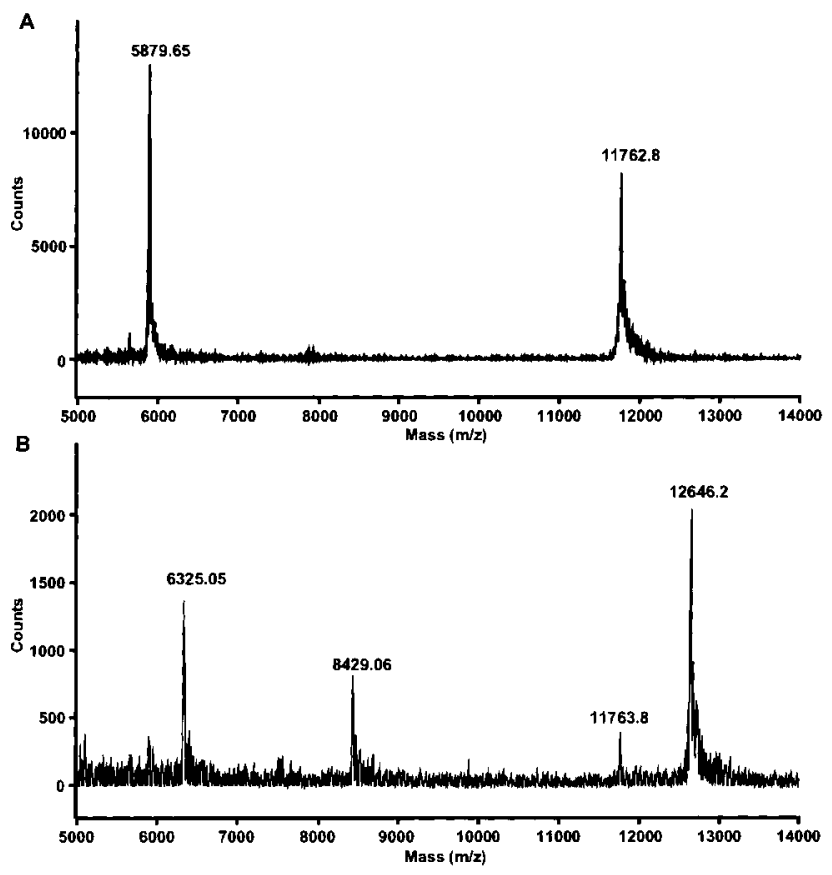

FIGURE 8: MALDI-TOF mass spectra of apo-ACP $\mathrm{Ais}_{\mathrm{His}}(\mathrm{A})$ and the in vitro synthesized holo- $\mathrm{ACP}_{\mathrm{His}}(\mathrm{B})$.

NTA columns and subjected to mass spectrometry. As shown in Figure 8, apo- $\mathrm{ACP}_{\text {His }}$ isolated from the control reaction yielded a mass of $11762.8 \mathrm{Da}$, which corresponds to the 1 -fold protonated species $(\mathrm{M}+\mathrm{H})^{+}$and deviates by $0.07 \%$ from the calculated mass of $11754.28 \mathrm{Da}$. In addition, a mass of $5879.65 \mathrm{Da}$ corresponding to the 2-fold protonated species $(\mathrm{M}+2 \mathrm{H})^{2+}$ was present. The putative holo- $\mathrm{ACP}_{\mathrm{His}}$ sample yielded a dominant mass of $12646.2 \mathrm{Da}$, but also contained a minor amount of apo- $\mathrm{ACP}_{\mathrm{His}}$ with a mass of $11763.8 \mathrm{Da}$. Subtraction gives a mass difference of 883.3 $\mathrm{Da}$, which corresponds exactly to the mass of the prosthetic group. The mass of $6325.05 \mathrm{Da}$ corresponds to the 2-fold protonated holo-ACP, whereas the identity of the 8429.06 Da peak is unknown. (ii) The prosthetic groups of an active E. coli citrate lyase preparation and of the in vitro synthesized $15.0 \mathrm{kDa} A C P$ were compared by reversed phase HPLC. For that purpose, E. coli citrate lyase containing a His-tagged ACP was overproduced and isolated by $\mathrm{Ni}^{2+}$-chelate affinity chromatgraphy (K. Schneider et al., unpublished results). The purified protein had citrate lyase activity $(\sim 8$ units $/ \mathrm{mg}$ of protein) and thus was present in the holo form, at least partially. The prosthetic group was cleaved off from citrate lyase and from the in vitro synthesized $15.0 \mathrm{kDa} A C P$ by alkaline treatment. As shown in Figure 9, reversed phase HPLC of the two resulting samples yielded identical chromatograms with peaks eluting at 7.0 and $14.3 \mathrm{~min}$. From the chromatographic behavior of reference samples (adenine, AMP, ADP, ATP, dephospho-CoA, and CoA), we concluded that the peak eluting at 14.3 min represented the entire prosthetic group, whereas the peak eluting at $7.0 \mathrm{~min}$ presumably was a degradation product. The identity of the peaks was confirmed by cochromatography (data not shown). Taken together, the results of mass spectrometry and HPLC analysis confirmed the assumption that the prosthetic group formed in vitro was identical with the one formed in vivo.

Nonconversion of AMP-ACP into Holo-ACP. The availability of the in vitro system for the conversion of apo- into holo-ACP allowed us to test if AMP-ACP can be converted to the holo form. For this purpose, apo- $\mathrm{ACP}_{\text {His }}(22 \mu \mathrm{M})$ was incubated with $\mathrm{CitX}_{\text {Strep }}(5 \mu \mathrm{M})$ and ATP $(1 \mathrm{mM})$ for 30 min at room temperature. Subsequently, the assay mixture was split, and one half was supplemented with $\mathrm{CitG}_{\mathrm{His}}(\sim 4$ $\mu \mathrm{M})$ and dephospho-CoA $(1 \mathrm{mM})$ and the other half with $\mathrm{CitG}_{\mathrm{His}}(\sim 4 \mu \mathrm{M})$ only. The mixtures were incubated for an additional $30 \mathrm{~min}$. At different times, samples were taken and subjected to SDS-PAGE. As shown in Figure 10, apo$\mathrm{ACP}_{\mathrm{His}}$ was completely converted to $\mathrm{AMP}-\mathrm{ACP}_{\mathrm{His}}$ after incubation for 30 min with $\mathrm{CitX}_{\text {Strep }}$ and ATP. However, no conversion of $\mathrm{AMP}-\mathrm{ACP}_{\mathrm{His}}$ into holo- $\mathrm{ACP}_{\mathrm{His}}$ was observed after incubation with $\mathrm{CitG}_{\mathrm{His}}$ and dephospho-CoA. This result 

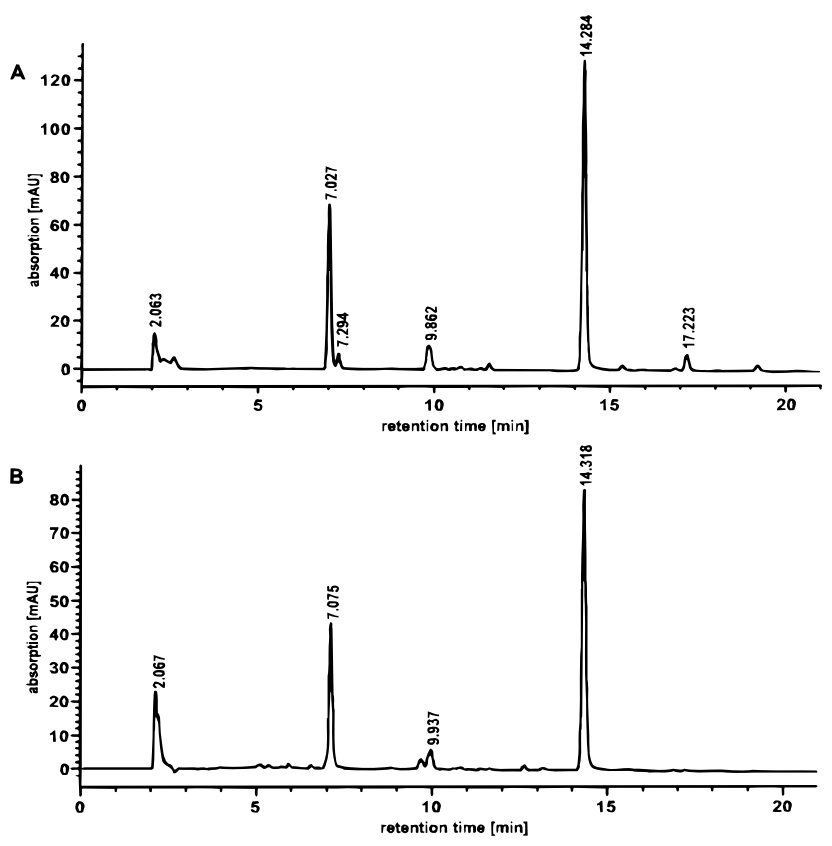

FIGURE 9: Reversed phase HPLC of the prosthetic group obtained after alkaline treatment of purified $E$. coli citrate lyase (A) and of the putative holo-ACP formed in vitro by incubation of apo-ACP with CitG, CitX, ATP, and dephospho-CoA (B). The samples were treated with $0.1 \mathrm{M} \mathrm{NaOH}$ for $30 \mathrm{~min}$ at $65^{\circ} \mathrm{C}$ to cleave off the prosthetic group. After $\mathrm{pH}$ adjustment to about 5 by $\mathrm{HCl}$ addition and removal of the precipitated protein by centrifugation, the compounds cleaved off were subjected to HPLC analysis. For detection, the UV absorption at $254 \mathrm{~nm}$ was measured.

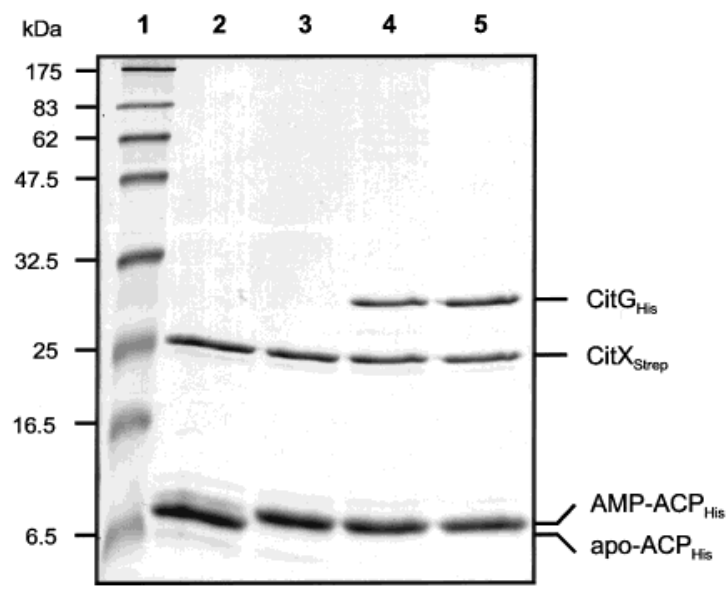

FIGURE 10: Nonconversion of AMP-ACP into holo-ACP. Apo$\mathrm{ACP}_{\text {His }}(22 \mu \mathrm{M})$ was incubated at room temperature with CitX $\mathrm{X}_{\text {Strep }}$ $(\sim 5 \mu \mathrm{M})$ and ATP $(1 \mathrm{mM})$. After $30 \mathrm{~min}$, the assay mixture was split, and one half was supplemented with $\mathrm{CitG}_{\mathrm{His}}(\sim 4 \mu \mathrm{M})$ and dephospho-CoA $(1 \mathrm{mM})$ and the other half with $\mathrm{CitG}_{\mathrm{His}}(\sim 4 \mu \mathrm{M})$ only. The two mixtures were incubated for an additional $30 \mathrm{~min}$. Samples were taken immediately after the start of the reaction with ATP (lane 2), 30 min later (lane 3), and 30 min after the addition of $\mathrm{CitG}_{\mathrm{His}}$ and dephospho-CoA (lane 4) or of $\mathrm{CitG}_{\mathrm{His}}$ only (lane 5). The samples were mixed with SDS sample buffer and subjected to SDS-PAGE. Lane 1 contained a protein standard. The gel was stained with Coomassie brilliant blue.

strongly implied that $\mathrm{AMP}-\mathrm{ACP}_{\mathrm{His}}$ is not an intermediate in the synthesis of holo-ACP, but a byproduct formed by CitX in the absence of its natural substrate. Therefore, holo-ACP formation most likely proceeds via the initial formation of a prosthetic group precursor from dephospho-CoA and ATP by CitG. This precursor is subsequently transferred to apo-
ACP by CitX. According to the structure of the prosthetic group and to the fact that ATP but not ADP or AMP served as the substrate, the prosthetic group precursor presumably is $2^{\prime}-\left(5^{\prime \prime}\right.$-triphosphoribosyl)-3'-dephospho-CoA.

\section{DISCUSSION}

Citrate lyase carries a $2^{\prime}$-(5'"-phosphoribosyl)-3'-dephospho-CoA prosthetic group (Figure 1B). In this work, we have identified the genes and the precursors required for the biosynthesis of this prosthetic group, and we provide strong evidence for the function of the enzymes involved. In a first set of experiments, we showed that in E. coli the proteins encoded by citX and citG are essential for the formation of an active citrate lyase. If both genes were expressed together with citCDEF, holo-ACP was formed and an active citrate lyase was present in the cells. In the absence of CitX, only the apo-ACP was formed, whereas in the absence of CitG, an intermediate-sized X-ACP was synthesized (Figure 3). $\mathrm{X}$-ACP was identified as AMP-ACP, with AMP attached to serine-14 of the ACP, i.e., to the same residue that carries the prosthetic group. The latter result indicated that CitX possesses ACP adenylyltransferase activity in vivo. This was subsequently confirmed in vitro with purified CitX and apoACP plus ATP as substrates. However, whereas in vivo only ATP was used as a substrate by CitX, in vitro CTP, GTP, and UTP were also accepted. Thus, CitX functions as an ACP nucleotidyltransferase (apo-ACP + NTP $\rightarrow$ NMP-ACP $\left.+\mathrm{PP}_{\mathrm{i}}\right)$.

To answer the question of whether AMP-ACP is an intermediate in the formation of holo-ACP or a byproduct formed by CitX only in the absence of CitG, we established an in vitro system that allowed the conversion of apo-ACP into holo-ACP exclusively with purified components. The identity of the prosthetic groups synthesized in vivo and in vitro was confirmed by their identical behavior during reversed phase HPLC. Moreover, the mass difference of apoACP and in vitro synthesized holo-ACP corresponded exactly to the calculated mass of the prosthetic group. For unknown reasons, it was not possible to detect the tryptic peptide carrying the entire prosthetic group by MALDI-TOF mass spectrometry. By means of the in vitro system, we unequivocally identified ATP and dephospho-CoA as sole precursors of the prosthetic group and showed that CitG and CitX are the only enzymes required for its synthesis. Remarkably, ATP could not be replaced by CTP, GTP, or UTP in the process of holo-ACP formation.

Attempts to convert AMP-ACP to holo-ACP by incubation with CitG and dephospho-CoA failed completely (Figure 10). Therefore, AMP-ACP is not an intermediate during the formation of holo-ACP, but an artificial byproduct formed only if the natural substrate of CitX is absent. Taken together, our results clearly indicate that the first step in the formation of holo-ACP is the synthesis of a precursor of the prosthetic group from ATP and dephospho-CoA catalyzed by CitG. According to the structure of the prosthetic group, this precursor presumably is $2^{\prime}$-(5' $5^{\prime \prime}$-triphosphoribosyl)-3'-dephospho-CoA. In this reaction, ATP cannot be replaced by CTP, GTP, or UTP. In the second step, the prosthetic group precursor and apo-ACP are converted to holo-ACP and pyrophosphate in a CitX-catalyzed reaction. Preliminary experiments strongly support this pathway; we have isolated 


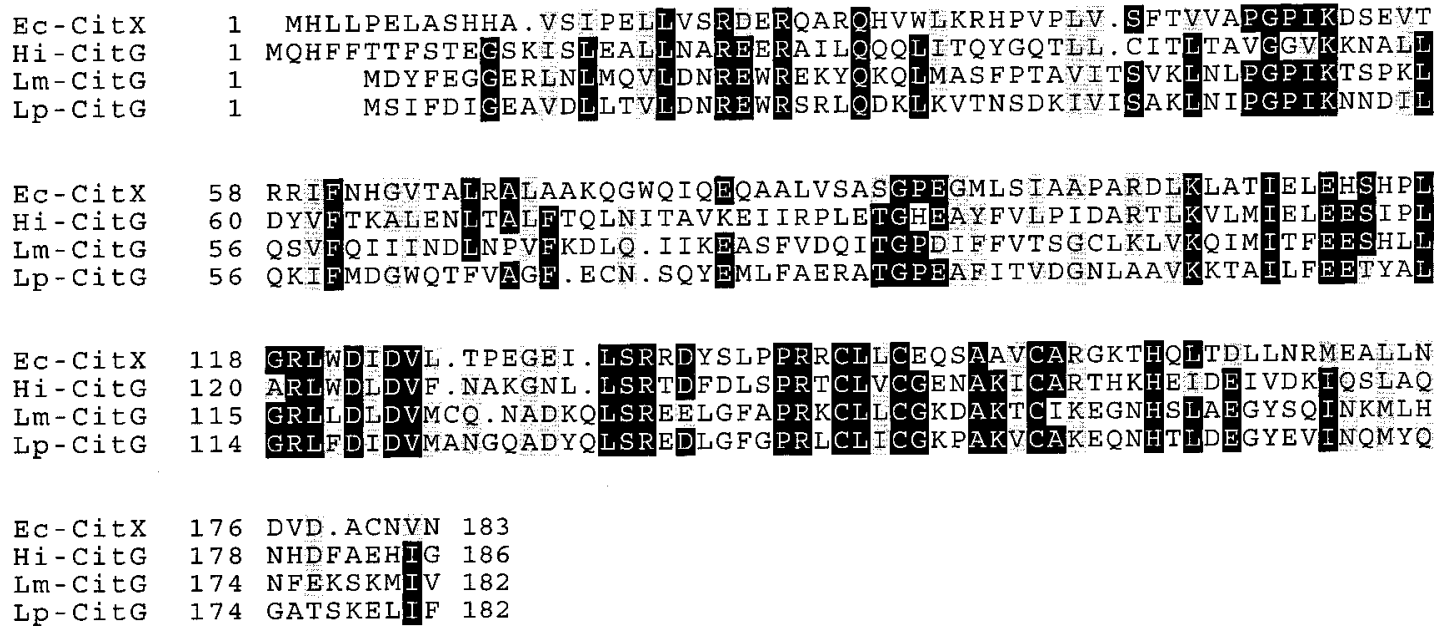

FIGURE 11: Sequence alignment of the N-terminal portions of the CitG proteins from H. influenzae (Hi), L. mesenteroides (Lm), and L. paramesenteroides $(\mathrm{Lp})$ with the CitX protein of $E$. coli $(\mathrm{Ec})$. Note that the $H$. influenzae CitG protein used in this alignment contains 49 additional amino acids at the N-terminus compared to Swissprot database entry P44458. The sequence shown here starts at a TTG codon located $181 \mathrm{bp}$ downstream of the citF stop codon, whereas the P44458 sequence starts at a GGT codon located 328 bp downstream of citF.

by HPLC a compound that is formed in vitro by CitG from ATP and dephospho-CoA, and we showed that this compound and apo-ACP are subsequently converted to holo-ACP by CitX.

Since the E. coli citX gene can complement the $K$. pneumoniae citCDEFG genes in the formation of an active citrate lyase, it is obvious that also $K$. pneumoniae must possess a citX-like gene. The fact that it is not part of the citCDEFG cluster might be accidental, but could also reflect the fact that transcriptional regulation of the citX gene differs from that of the citC operon $(21,22)$. Attempts to clone the $K$. pneumoniae cit $X$ gene by heterologous hybridization with an E. coli citX probe or by PCR with degenerated primers were not successful (data not shown). However, a search with the $E$. coli $\mathrm{CitX}$ protein against the sequences available from the K. pneumoniae strain MGH78578 genome sequencing project performed at the Washington University School of Medicine (St. Louis, MO; http://genome.wustl.edu/gsc/ Projects/bacterial/klebsiella/klebsiella.shtml) revealed the presence of a sequence encoding a putative CitX protein. Experiments are in progress to clone the corresponding region by PCR from the $K$. pneumoniae strain (ATCC13882) used in our studies and to analyze the regulation of the putative citX gene and the function of its protein product.

In the citrate lyase gene clusters of $H$. influenzae, $L$. mesenteroides, and $L$. paramesenteroides, citX is not a separate gene but fused with $\mathrm{cit} G$, forming its $5^{\prime}$-terminal part (Figure 2). The $180 \mathrm{~N}$-terminal amino acids of these extended $\mathrm{CitG}$ proteins are 26-30\% identical to those of CitX from E. coli (Figure 11). According to our results, the CitG proteins from $H$. influenzae, L. mesenteroides, and $L$. paramesenteroides are bifunctional enzymes. The finding that CitX and CitG are fused in some bacteria underlines the fact that these proteins act in concert. One can therefore envisage that the prosthetic group precursor is not released by $\mathrm{CitG}$, but immediately captured by $\mathrm{CitX}$ and transferred to apoACP.

The 2'-(5'-phosphoribosyl)-3'-dephospho-CoA prosthetic group is not unique to citrate lyase, but also occurs in citramalate lyase and malonate decarboxylase. Analysis of the gene clusters for malonate decarboxylase revealed that

\begin{tabular}{ll} 
"Kp-CitX" & LEQSHPLGRLWDIDVICPQ \\
"VC-CitX" & IEREHPLGRLMDIDVIDVD \\
"St-CitX" & LEQRYPLGRLWDIDVLTAE \\
"Sp-CitX" & LETELPIGRLMDLDVLVLQ \\
"Ef-CitX" & IEETHPYGRLVDIDVLWGN \\
"Aa-CitX" & LEESLPLARLWDLDVFDHE \\
Lp-CitG & FEETYALGRLFDIDVMANG \\
Lm-CitG & FEESHLLGRLLDLDVMCQN \\
Hi-CitG & LEESIPLARLWDLDVFNAK \\
EC-CitX & LEHSHPLGRLWDIDVLTPE \\
\hline Kp-MdcG & ATEIPVLHAASDLDLLIRA \\
Pp-MdcG & ATGMEVVHAGSDLDLLLRT \\
AC-MdcG & LTQEAYVRATSDLDLVLYP \\
Mr-MadK & ATCLPYTTDQSDLDLNTDS \\
\hline EC-GInEC & KLGGWELGYSSDLDLIFLH \\
Hi-GInEC & KLGGIELGYKSDLDLVFLY \\
Mt-GlnEC & RLGGAELGYGSDADVMFVC \\
EC-GInEN & KLGGGELNFSSDIDLIFAW \\
Hi-GInEN & KLGGFELNFSSDIDLIFTY \\
Mt-GlnEN & KCGARELNYVSDVDVIFVA
\end{tabular}

FIGURE 12: Alignment of a conserved sequence motif identified in enzymes with proven (CitX and GlnE) or proposed protein adenylyltransferase activity, i.e., citrate lyase apo-ACP ATase (CitX and $\mathrm{CitG}$ ), malonate decarboxylase apo-ACP ATase (MdcG and $\mathrm{MadK}$ ), and glutamine synthetase ATase (GlnEC, C-terminal adenylylation domain, and GlnEN, N-terminal deadenylylation domain). The strictly conserved aspartate residues and the highly conserved residues within the CitX family are shown in bold. The members in quotation marks were obtained by TBLASTN searches (46) of unfinished genome projects (http://www.ncbi.nlm.nih.gov/ Microb_blast/unfinishedgenome.html), and thus, their sequence and designation are preliminary: Aa, Actinobacillus actinomycetemcomitans; Ac, A. calcoaceticus; Ec, E. coli; Ef, Enterococcus faecalis; Hi, H. influenzae; Kp, K. pneumoniae; Lm, L. mesenteroides; Lp, L. paramesenteroides; Mr, M. rubra; Mt, Mycobacterium tuberculosis; Pp, P. putida; Sp, Streptococcus pyogenes; St, Salmonella typhi; Vc, Vibrio cholerae.

madG from $M$. rubra (41) and $m d c B$ from $K$. pneumoniae (42), Pseudomonas putida (43), and A. calcoaceticus (19) encode proteins whose sequences are $34-37 \%$ identical to that of CitG from $K$. pneumoniae. None of these proteins had an N-terminal extension that was similar to CitX, and also none of the sequences of the other mad and $m d c$ gene products were unequivocally similar to that of CitX. How- 
ever, the proteins encoded by $\operatorname{madK}$ from $M$. rubra and by $m d c G$ from $K$. pneumoniae, $P$. putida, and A. calcoaceticus may represent the functional equivalents to the E. coli $\mathrm{CitX}$ protein, since they contain one short amino acid stretch that is similar to CitX and, importantly, also to glutamine synthetase adenylyltransferase, the $g \ln E$ gene product (44). GlnE, a central regulator of nitrogen assimilation in enterobacteria and several other bacterial species (ref 44 and references therein), is the best-studied example of enzymes that adenylylate other proteins. It possesses two catalytic activities, i.e., the ATP-dependent adenylylation of a specific tyrosine residue of glutamine synthetase (EC 6.3.1.2) with the concomitant formation of pyrophosphate and the $\mathrm{P}_{\mathrm{i}}{ }^{-}$ dependent deadenylylation with the concomitant formation of ADP. It was recently shown for $E$. coli GlnE (945 amino acids) that the adenylylation activity resides on the C-terminal domain, whereas the deadenylylation activity resides on the $\mathrm{N}$-terminal domain (45).

In Figure 12, an alignment of the conserved amino acid stretch is shown, including sequences from unfinished genome projects (http://www.ncbi.nlm.nih.gov/BLAST/unfinishedgenome.html). It is evident that the DXD motif is strictly conserved and that $\mathrm{MadK}, \mathrm{MdcG}$, and MdcE are more similar to GlnE than to the CitX family. Although the functional significance of this amino acid stretch is not yet known, the motif G/A-R-L-X-D-L/I-D-V could represent a signature sequence for proteins with citrate lyase apo-ACP adenylyltransferase activity. The low level of overall sequence identity of MdcG and MadK to CitX $(<22 \%)$ can be explained by the fact that their substrates, i.e., the apoACPs of malonate decarboxylase and citrate lyase, also contain only limited regions with sequence identity $(<26 \%)$. Parallel to our work on citrate lyase, it was shown that the synthesis of the K. pneumoniae malonate decarboxylase holo$\mathrm{ACP}$ is dependent on $\mathrm{MdcB}$ and $\mathrm{MdcG}$, supporting the proposed functional equivalence of $\mathrm{CitX}$ and $\mathrm{MdcG}$ ( $\mathrm{S}$. Hoenke, M. Wild, and P. Dimroth, unpublished results).

\section{ACKNOWLEDGMENT}

We thank Sergio Gilardi for his contribution to this work during the "Semester-Arbeit", Stefan Hoenke and Markus Wild for assistance in the chromatographic identification of AMP, Dr. Ulrich Matthey and Yvonne Appoldt for competent help during the performance of the HPLC analysis, Dr. Georg Kaim for a gift of chromosomal E. coli DNA, and Dr. Margareta Meyer for carefully reading the manuscript. We are most grateful to Dr. Manfredo Quadroni for expert performance of the mass spectrometric analysis.

\section{REFERENCES}

1. Bott, M. (1997) Arch. Microbiol. 167, 78-88.

2. Dimroth, P. (1988) in The Roots of Modern Biochemistry (Kleinkauf, H., Döhren, H. v., and Jaenicke, L., Eds.) pp 191204, Walter de Gruyter and Co., Berlin.

3. Antranikian, G., and Giffhorn, F. (1987) FEMS Microbiol. Rev. 46, 175-198.

4. Subramanian, S., and Sivaraman, C. (1984) J. Biosci. 6, 379401.

5. Dimroth, P., and Eggerer, H. (1975) Eur. J. Biochem. 53, 227235.

6. Singh, M., Srere, P. A., Klapper, D. G., and Capra, J. D. (1976) J. Biol. Chem. 251, 2911-2915.
7. Dimroth, P., Dittmar, W., Walther, G., and Eggerer, H. (1973) Eur. J. Biochem. 37, 305-315.

8. Dimroth, P. (1976) Eur. J. Biochem. 64, 269-281.

9. Robinson, J. B., Jr., Singh, M., and Srere, P. A. (1976) Proc. Natl. Acad. Sci. U.S.A. 73, 1872-1876.

10. Singh, M., Robinson, J. B., Jr., and Srere, P. A. (1977) J. Biol. Chem. 252, 6061-6068.

11. Beyreuther, K., Böhmer, H., and Dimroth, P. (1978) Eur. J. Biochem. 87, 101-110.

12. Oppenheimer, N. J., Singh, M., Sweeley, C. C., Sung, S.-J., and Srere, P. A. (1979) J. Biol. Chem. 254, 1000-1002.

13. Buckel, W., Buschmeier, V., and Eggerer, H. (1971) HoppeSeyler's Z. Physiol. Chem. 352, 1195-1205.

14. Schmellenkamp, H., and Eggerer, H. (1974) Proc. Natl. Acad. Sci. U.S.A. 71, 1987-1991.

15. Dimroth, P., and Eggerer, H. (1975) Proc. Natl. Acad. Sci. U.S.A. 72, 3458-3462.

16. Dimroth, P., and Loyal, R. (1977) FEBS Lett. 76, 280-283.

17. Berg, M., Hilbi, H., and Dimroth, P. (1996) Biochemistry 35, 4689-4696.

18. Schmid, M., Berg, M., Hilbi, H., and Dimroth, P. (1996) Eur. J. Biochem. 237, 221-228.

19. Koo, J. H., and Kim, Y. S. (1999) Eur. J. Biochem. 266, 683690.

20. Bott, M., and Dimroth, P. (1994) Mol. Microbiol. 14, 347356.

21. Bott, M., Meyer, M., and Dimroth, P. (1995) Mol. Microbiol. $18,533-546$.

22. Meyer, M., Dimroth, P., and Bott, M. (1997) J. Mol. Biol. 269, 719-731.

23. Kaspar, S., Perozzo, R., Reinelt, S., Meyer, M., Pfister, K., Scapozza, L., and Bott, M. (1999) Mol. Microbiol. 33, 858872.

24. Buckel, W., Ziegert, K., and Eggerer, H. (1973) Eur. J. Biochem. 37, 295-304.

25. Blattner, F. R., Plunkett, G., III, Bloch, C. A., Perna, N. T., Burland, V., Riley, M., Collado-Vides, J., Glasner, J. D., Rode, C. K., Mayhew, G. F., Gregor, J., Davis, N. W., Kirkpatrick, H. A., Goeden, M. A., Rose, D. J., Mau, B., and Shao, Y. (1997) Science 277, 1453-1474.

26. Pos, K. M., Dimroth, P., and Bott, M. (1998) J. Bacteriol. 180, 4160-4165.

27. Sambrook, J., Fritsch, E. F., and Maniatis, T. (1989) Molecular Cloning. A Laboratory Manual, Cold Spring Harbor Laboratory Press, Cold Spring Harbor, NY.

28. Studier, F. W., and Moffatt, B. A. (1986) J. Mol. Biol. 189, 113-130.

29. Yanisch-Perron, C., Vieira, J., and Messing, J. (1985) Gene 33, 103-119.

30. Hansen, F. G., Nielsen, J., Riise, E., and von Meyenburg, K. (1981) Mol. Gen. Genet. 183, 463-472.

31. Chang, A. C. Y., and Cohen, S. N. (1978) J. Bacteriol. 134, $1141-1156$.

32. Schmidt, T. G. M., Koepke, J., Frank, R., and Skerra, A. (1996) J. Mol. Biol. 255, 753-766.

33. Tabor, S. (1992) in Short Protocols in Molecular Biology (Ausubel, F. M., et al., Eds.) pp 16-6-16-10, John Wiley and Sons, New York.

34. Smith, P. K., Krohn, R. I., Hermanson, G. T., Mallia, A. K., Gartner, F. H., Provenzano, M. D., Fujimoto, E. K., Goeke, N. M., Olson, B. J., and Klenk, D. C. (1985) Anal. Biochem. $150,76-85$.

35. Voss, S., and Skerra, A. (1997) Protein Eng. 10, 975-982.

36. Laemmli, U. K. (1970) Nature 227, 680-685.

37. Jaworek, D., and Welsch, J. (1985) in Methods of Enzymatic Analysis (Bergmeyer, H. U., Ed.) Vol. VII, pp 365-370, VCH, Weinheim, Germany.

38. Fleischmann, R. D., Adams, M. D., White, O., Clayton, R. A., Kirkness, E. F., Kerlavage, A. R., Bult, C. J., Tomb, J.-F., Dougherty, B. A., Merrick, J. M., McKenney, K., Sutton, G., FitzHugh, W., Fields, C., Gocayne, J., Scott, J., Shirley, R., Liu, L.-I., Glodek, A., Kelley, J. M., Weidman, J. F., Phillips, C. A., Spriggs, T., Hedblom, E., Cotton, M. D., Utterback, T. R., Hanna, M. C., Nguyen, D. T., Saudek, D. M., Brandon, 
R. C., Fine, L. D., Fritchman, J. L., Fuhrmann, J. L., Geoghagen, N. S. M., Gnehm, C. L., McDonald, L. A., Small, K. V., Fraser, C. M., Smith, H. O., and Venter, J. C. (1995) Science 269, 496-512.

39. Bekal, S., Beeumen, J. V., Samyn, B., Garmyn, D., Henini, S., Diviès, C., and Prévost, H. (1998) J. Bacteriol. 180, 647654.

40. Martin, M., Corrales, M. A., de Mendoza, D., López, P., and Magni, C. (1999) FEMS Microbiol. Lett. 174, 231-238.

41. Berg, M., Hilbi, H., and Dimroth, P. (1997) Eur. J. Biochem. $245,103-115$.

42. Hoenke, S., Schmid, M., and Dimroth, P. (1997) Eur. J. Biochem. 246, 530-538.
43. Chohnan, S., Kurusu, Y., Nishihara, H., and Takamura, Y. (1999) FEMS Microbiol. Lett. 174, 311-319.

44. Reitzer, L. J. (1996) in Escherichia coli and Salmonella (Neidhardt, F. C., Ed.) 2nd ed., Vol. 1, pp 391-407, ASM Press, Washington, DC.

45. Jaggi, R., van Heeswijk, W. C., Westerhoff, H. V., Oliis, D. L., and Vasudevan, S. G. (1997) EMBO J. 16, 5562-5571.

46. Altschul, S. F., Madden, T. L., Schäffer, A. A., Zhang, J., Zhang, Z., Miller, W., and Lipman, D. J. (1997) Nucleic Acids Res. 25, 3389-3402.

BI000401R 